\title{
Motywacja jako determinant rozpoczęcia kariery zawodowej i powodzenia na rynku pracy
}

\author{
Monika Jadacka*, Tomasz Zalega**
}

Celem artykutu jest wykazanie, na podstawie materiału faktograficznego, że motywacja jest postrzegana przez studentów jako determinant utatwiający rozpoczęcie kariery zawodowej $i$ dalsze powodzenie na rynku pracy. Struktura artykutu jest następująca: po omówieniu metodologii i zatożeń badania skoncentrowano się na aspekcie teoretycznym istoty motywacji $i$ motywowania. W dalszej części artykutu, na podstawie materiału faktograficznego, przeanalizowano kluczowe determinanty wptywajace na rozpoczęcie kariery zawodowej przez mtodych ludzi $i$ ich dalsze powodzenie na rynku pracy. Podsumowanie rozważań $i$ ważniejsze wnioski kończa niniejszy artykut.

Słowa kluczowe: motywacja, motywowanie, miękkie kompetencje, czynniki pracy, motywatory pozapłacowe, plany zawodowe.

Nadesłany: 07.11.2012 | Zaakceptowany do druku: 12.12.2012

\section{Motivation as a determinant of starting a professional career and of being successful in the labour market}

The article uses factual information to demonstrate that the students perceive motivation as a factor likely to facilitate their start into professional careers and making them successful. The article is structured as follows. The presentation of the research methodology and assumptions is followed by a discussion of the theoretical aspects of motivation and motivating. In the next section, factors causing young people to launch professional careers and determining their subsequent successes in the labour market are analysed based on factual information. The article ends with a summation of the discussion and major conclusions.

Keywords: motivation, motivating, soft skills, human factor, non-wage incentives, career plans.

Submitted: 07.11.2012 | Accepted: 12.12.2012

JEL: D03; J39; M59

\footnotetext{
Mgr Monika Jadacka

Adres do korespondencji: e-mail: mjadacka@o2.pl.

** Prof. UW dr hab. Tomasz Zalega - Uniwersytet Warszawski

Adres do korespondencji: Wydział Zarządzania Uniwersytetu Warszawskiego, ul. Szturmowa 1/3, 02-678

Warszawa, e-mail: tomasz.zalega@wp.pl.
} 


\section{Wprowadzenie}

Praca ludzka i kariera zawodowa odgrywają bardzo istotną rolę w życiu wspó1czesnego człowieka. $\mathrm{Z}$ tego też względu motywacja do działania, a także zachowania i system wartości związanych $\mathrm{z}$ pracą są przedmiotem zainteresowania nauk społecznych, takich jak: ekonomia, socjologia, psychologia czy etyka. Praca jest zatem zjawiskiem interdyscyplinarnym, modelowanym przez liczne uwarunkowania. Szczególny nacisk kładzie się przede wszystkim na determinanty psychologiczne, które w największym stopniu motywują ludzi do działania.

Zmienność i niestabilność gospodarki i rynku pracy (przez dynamiczny rozwój atypowych form zatrudnienia) sprawiają, że młodzi ludzie, którzy dopiero rozpoczynają swoją karierę zawodową, stają przed coraz trudniejszymi wyzwaniami. Ponadto procesy globalizacji i internacjonalizacji gospodarki światowej oraz permanentny rozwój nauki i techniki wywierają istotny wpływ na przemiany zachodzące w różnych dziedzinach życia człowieka. Zmieniają się nie tylko postawy jednostek i styl ich życia, lecz przede wszystkim proces kariery zawodowej i motywacja do jej rozpoczęcia.

\section{Metodologia badania}

W dzisiejszych czasach młodzi ludzie coraz częściej zadają sobie pytanie, czy poziom ich motywacji do działania wywiera wpływ na rozpoczęcie kariery zawodowej. Należy w tym miejscu zaznaczyć, że zarówno poziom motywacji studentów do rozpoczęcia kariery zawodowej, jak i skuteczność wykorzystywanych przez pracodawców motywatorów jest tematem ciagłych dyskusji. Mając to na uwadze, w artykule sformułowano dwie hipotezy główne:

1. Posiadanie sprecyzowanych planów zawodowych na przyszłość pozostaje w ścisłym związku z subiektywnie ocenianym poziomem motywacji.

2. Zaangażowanie w wykonywane czynności pozostaje w ścisłej korelacji z poziomem własnej motywacji.

Sformułowano również trzy hipotezy cząstkowe:

1. Występują różnice w grupie kobiet i mężczyzn w ocenie poziomu własnej motywacji do rozpoczęcia pracy zawodowej.
2. Istnieją różnice $\mathrm{w}$ grupie kobiet i mężczyzn w postrzeganiu zależności między znajomością języków obcych a rozwojem kariery zawodowej.

3. Otrzymywanie pochwał od przełożonego jest motywatorem odbieranym inaczej przez kobiety i mężczyzn.

Do przeprowadzenia badań pierwotnych ułożony został kwestionariusz ankiety składający się z 18 pytań zamkniętych oraz 4 pytań metryczkowych. Na sześć pytań zamkniętych (o charakterze nominalnym) należało odpowiedzieć, zaznaczając jedną z podanych odpowiedzi, na pięć pytań ( $\mathrm{z}$ odpowiedziami o charakterze porządkowym) - zaznaczając jedną z czterech możliwości, natomiast na pozostałe - wartościując wszystkie podane zagadnienia na skalach porządkowych Lickerta. Skale porządkowe w kwestionariuszu ankiety składają się z czterech odpowiedzi: [1] - „zdecydowanie nie”, „zdecydowanie niskie”, „zdecydowanie nieważne”, „zdecydowanie nieistotne”, bądź ,zdecydowanie nieskuteczne”, [2] - „raczej nie”, „raczej niskie”, „raczej nieważne”, „raczej nieistotne”, bądź „raczej nieskuteczne”, [3] - „raczej tak”, „raczej wysokie”, „raczej ważne”, „raczej istotne”, bądź „raczej skuteczne”, [4] - „zdecydowanie tak”, zdecydowanie wysokie”, ,zdecydowanie ważne”, „zdecydowanie istotne”, bądź „zdecydowanie skuteczne".

Przeprowadzone przez dobór losowy badanie miało charakter grupowy, zaś respondenci, jeszcze przed jego przeprowadzeniem, zostali poinformowani o celu badania i jego anonimowym charakterze. Badania ankietowe zostały przeprowadzone w listopadzie 2011 r. wśród studentów studiów niestacjonarnych Wydziału Zarządzania Uniwersytetu Warszawskiego. Respondenci wzięli udział w badaniu bezpłatnie, natomiast uzyskane informacje posłużyły do weryfikacji postawionych w pracy hipotez.

Wyniki przeprowadzonego badania poddano analizie statystycznej $\mathrm{w}$ programie SPSS for Windows (zgodnie z problematyką badawczą pracy). Jednakże z uwagi na ograniczenia tekstowe w artykule zostały przedstawione i przeanalizowane wyłącznie te wyniki, które okazały się istotne statystycznie.

W celu osiągnięcia założonych celów pracy badaniami została objęta próba 110 osób. Uczestniczyły w nim zarówno kobiety 
(57,3\% próby), jak i mężczyźni $(42,7 \%$ próby). Badanie zostało przeprowadzone na Wydziale Zarządzania Uniwersytetu Warszawskiego, w grupie studentów: pierwszego roku studiów DSFiR wieczorowych (przebadanych zostało 60 osób z 124 studentów tego kierunku) oraz drugiego roku studiów DSM wieczorowych (50 uczestników badania ze 168 słuchaczy tego kierunku) (tabela 1).

Tabela 1. Opis próby badawczej

\begin{tabular}{|c|c|c|c|}
\hline \multicolumn{2}{|c|}{ Statystyki } & Kobiety & $\begin{array}{c}\text { Mężczyź- } \\
\text { ni }\end{array}$ \\
\hline \multirow{6}{*}{ Wiek } & Średnia & 19,70 & 19,91 \\
\hline & Mediana & 20 & 20 \\
\hline & Dominanta & 19 & 20 \\
\hline & $\begin{array}{l}\text { Odchylenie } \\
\text { standardowe }\end{array}$ & 0,854 & 1,816 \\
\hline & Minimum & 19 & 19 \\
\hline & Maximum & 23 & 31 \\
\hline \multirow{6}{*}{$\begin{array}{c}\text { Aktualny } \\
\text { rok stu- } \\
\text { diów }\end{array}$} & Średnia & 1,48 & 1,43 \\
\hline & Mediana & 1 & 1 \\
\hline & Dominanta & 1 & 1 \\
\hline & $\begin{array}{l}\text { Odchylenie } \\
\text { standardowe }\end{array}$ & 0,503 & 0,500 \\
\hline & Minimum & 1 & 1 \\
\hline & Maximum & 2 & 2 \\
\hline \multirow{2}{*}{$\begin{array}{c}\text { Miejsce } \\
\text { zamiesz- } \\
\text { kania }\end{array}$} & Mediana & \multirow{2}{*}{\multicolumn{2}{|c|}{$\begin{array}{l}\text { Miasto duże - } \\
\text { powyżej } 100 \text { tys. } \\
\text { mieszkańców }\end{array}$}} \\
\hline & Dominanta & & \\
\hline
\end{tabular}

Źródło: opracowanie własne.

Średnia wieku kobiet uczestniczących w badaniu (19,7 lat) jest mniej zróżnicowana niż średnia wieku mężczyzn $(19,91$ lat). Najstarszy uczestnik badania miał 31 lat, a najmłodsi respondenci byli w wieku 19 lat. Wśród osób badanych dominowali mieszkańcy dużych miast - powyżej 100 tys. mieszkańców - oraz studenci i studentki pierwszego roku.

\section{Istota motywacji i motywowania - aspekt teoretyczny}

W naszym życiu ciągle przeplatają się szczęście i pech, powodzenie i porażka; dokładnie tak samo, jak następują po sobie odpływy i przypływy morza. Musi więc być coś, co sprawi, że nie będziemy chcieli się poddać, że na dobrym wyniku będzie nam ciągle bardzo zależało. Do tego niezbędna jest motywacja. Nie możemy jednak zapomnieć o tym, że motywacja to nie wszystko, zaś wszystko bez motywacji jest niczym (Altmann, 1997, s. 255-256). Czym jest więc motywacja? Określana jest ona immanentnym stanem jednostki o charakterze jakościowym; zbiorem procesów zarówno psychologicznych, jak i fizjologicznych, zdeterminowanych potrzebą oraz opisujących podstawę zachowań i ich modyfikacji. Jest stanem gotowości człowieka do podjęcia określonego działania. Współczesna psychologia posługuje się terminem "motyw” do określania różnego rodzaju zjawisk. Motywami nazywane są zarówno intuicyjne impulsy, popędy biologiczne i apetyt, jak i zainteresowania, doświadczane emocje oraz cele życiowe, marzenia i życzenia (Erpenbeck, 1984, s. 49).

$\mathrm{Z}$ natężeniem motywacji i presji do wykonania zadania nie należy jednak przesadzać, gdyż mogą one paraliżować prawidłowe spełnianie obowiązków, wywołując zbyt wysoki poziom stresu lub nawet bunt. Dotyczące tego zjawiska prawo Bircha głosi, że człowiek najsprawniej rozwiązuje problemy, osiagga najlepsze efekty przy średniej motywacji, gorsze przy zbyt słabej lub zbyt wysokiej (Borkowska, 1985, s. 9). Należy więc najpierw dogłębnie poznać indywidualną motywację i jej determinanty, gdyż są one najczęściej sprawą wewnętrzną każdego człowieka, żeby później można było przedsięwziąć odpowiednie środki i rozpocząć rozsądne i skuteczne działania prowadzące do podwyższenia efektywności pracy. Kształtowanie motywacji, czyli proces wpływania na nią, określamy motywowaniem. Ma ono (w odróżnieniu od motywacji) wymiar funkcjonalny (Borkowska, 1985; Sekuła, 2008). Motywowanie do pracy jest procesem świadomego i celowego oddziaływania na motywację do pracy przez stwarzanie środków i możliwości realizacji ich oczekiwań (celów działania) oraz wartości dla osiągnięcia celów motywującego, z uwzględnieniem otoczenia obu stron procesu (Borkowska, 2006, s. 333). Innymi słowy, motywowanie polega na łączeniu celów pojedynczych jednostek z celami przełożonego, który jest zazwyczaj osoba motywującą. Jak widać, motywacja jest procesem dwustronnym, osadzonym na zasadzie sprzężenia zwrotnego. 
Motywowanie jest, obok wyznaczania celów, planowania, organizowania oraz kontrolowania i oceniania, jednym z etapów złożonego i wielofazowego procesu zarządzania zasobami ludzkimi. Aby zarządzanie to było efektywne, konieczne jest współgranie wszystkich wyżej wymienionych elementów (Jasiński, 2007, s. 14). Złożony proces kierowniczy narzuca konieczność posługiwania się zarówno bodźcami materialnymi, jak i ideowo-moralnymi; stosowania rozmaitych rozwiązań, usilnych starań oraz wszelkich wpływów i działań mających na celu skłonienie pracowników do kreatywnego wypełniania (samodzielnie bądź w grupie) obowiązków i zadań zleconych, tak by czerpali satysfakcję z pracy oraz by jej warunki były pomocne w kształtowaniu coraz lepszych atrybutów osobowości (Brady i Macleod 2011; Kozłowski 2009).

Badania z zakresu psychologii motywacji wskazują, że u człowieka mogą symultanicznie występować zróżnicowane motywy i formować się odmienne cele, tendencje motywacyjne. Wyraz temu daje kompleksowość motywacji i branie jej pod uwage przy selekcji celów. Motywacja do osiągnięcia celu (C) jest złożoną zależnością, zawierającą w sobie dążenia przeróżnych rodzajów motywacji i dającą się sformułować w postaci: $\mathrm{M}(\mathrm{c})=\mathrm{f}(\mathrm{Md}, \mathrm{Mt}, \mathrm{Mk}$, Mzk). Wybranie celu i rozpoczęcie działania wyznacza tzw. sytuację motywacyjna, w której wyszczególnia się (Reykowski, 1992, s. 93):

- dążenie dominujące (Md), determinujące wybór celu (wartość dodatnia, gdyż aktywizuje do działania);

- dążenia/motywy towarzyszące (Mt), wzmacniające obrany kierunek działalności dzięki niecodziennemu zbiegowi okoliczności (wartość dodatnia);

- dążenia konkurencyjne (Mk), aktywizujące do rozpoczęcia czynności dążących do celów, niedających dopasować się do obranego celu (wartość ujemna, gdyż zniechęca do działania);

- dążenia zmienne kontekstowe (Mzk), wskazujące na konieczność brania pod uwagę motywów sprzężonych $\mathrm{z}$ faktem, że rozpoczynane działania mogą być zgodne lub nie $\mathrm{z}$ upodobaniami i preferencjami odnośnie do poziomu podejmowanego ryzyka. Wymienione aspekty czynności są przyczynkiem do celów wspierających lub powstrzymujących konkretne działanie (wartość dodatnia lub ujemna, która adaptuje się do przeżywanych emocji).

Fundamentalną dziedziną ludzkiego życia jest praca zawodowa. Absorbuje ona znaczna część naszego czasu i energii. Nie dziwi więc, że tak głębokie zaangażowanie w nią musi mieć swoje źródła we wszelkiego rodzaju motywacji. Motywacja to proces, w wyniku którego dochodzi do pobudzenia, ukierunkowania i zorganizowania naszej aktywności, a inwestowanie siły i czasu w prace przez pracownika wynika przede wszystkim z (Adamiec, Kożusznik, 2000: 135-136):

- pojmowania pracy jako potrzebnej i cennej samej w sobie, przynoszącej poczucie satysfakcji i samorealizacji. W tej sytuacji pracownik będzie intensyfikował nakład swej pracy nawet bez dodatkowej motywacji;

- pojmowania pracy jako sposobu dotarcia do celu innego niż ona sama. W tej sytuacji pracownik będzie podporządkowywał nakład swej pracy nagrodom i profitom, które umożliwią mu spełnienie innych potrzeb.

Ze względu na rodzaj wartości, do jakich zmierza jednostka, rozróżnia się motywację wewnętrzną i motywację zewnętrzną. Celem motywacji wewnętrznej jest pozyskanie finalnych, autotelicznych wartości, natomiast motywacja zewnętrzna służy wyłącznie do osiagnnięcia instrumentalnych wartości; jest jedynie sposobem do uzyskania wartości ostatecznych, czyli dopięcia swego celu. Podział ten należy asocjować z koncepcją Herzberga, odróżniającą czynniki higieny od motywatorów. Znaczenie motywatorów, powodujących określone aktywności, przyporządkowuje się jedynie faktorom ukierunkowanym na wartości wewnętrzne, takie jak interesująca praca, sława czy przywództwo. Z kolei czynniki zewnętrzne (tzw. czynniki higieny), jak np. wynagrodzenie, nie powodują satysfakcji, niemniej jednak znoszą niezadowolenie, gdyż są narzędziem do urzeczywistnienia swych pragnień i wartości jako takich. Teoria Herzberga, informująca o tym, że czynniki higieny nie są motywatorami, została $\mathrm{z}$ czasem odrzucona, natomiast podział na motywację wewnętrzną i zewnętrzną stał się niezmiernie przydatny w tworzeniu motywacji do pracy (Juchnowicz, 2012; Kopertyńska, 2009; Zalega, 2012).

Wszyscy, którzy pragną kształtować motywację, powinni być świadomi tego, że 
ludzie poza źródłami siły nakłaniającej do zrobienia czegoś, mają tendencję do analizowania rzeczywistości oraz prognozowania efektów swojej pracy i wskutek tego do odbierania niektórych rzeczy jako bardziej lub mniej atrakcyjnych. Motywacja nie jest jedynie popychaniem, lecz także przyciaganiem. To rozróżnienie tworzy drugi podział rodzajów motywacji. Motywacja ,,do wejścia" występuje, gdy osoba chce być pracownikiem firmy, otrzymać stanowisko czy etat. Motywacja do pracy natomiast występuje w sytuacji, gdy dana osoba pragnie aktywnie funkcjonować wewnątrz firmy. Rozróżnia się dwa rodzaje motywacji do pracy. Pierwszy to motywacja do zadań, która występuje w sytuacji, gdy pracownik chce realizować określone zadania, gdyż są dla niego atrakcyjne, przyciagające oraz motywację do uczestnictwa, z którą mamy do czynienia, gdy pracownik pragnie brać udział i głęboko angażować się w koordynację prawidłowego funkcjonowania działów firmy (Adamiec i Kożusznik, 2000, s. 139-140).

Opisany podział rodzajów motywacji może być punktem wyjścia do sprecyzowania rzeczy, które są dla pracowników interesujące i przyciągające, a poza tym do przedstawienia dwóch form motywacji, czyli motywacji zadaniowej oraz motywacji systemowej. Jednak główna maksyma systemu wynagrodzeń powinna być implikacją idei zarządzania zasobami ludzkimi głoszącej, że finalnym źródłem powodzenia organizacji są ludzie. Oznacza to, że wprawdzie struktura wynagrodzeń ma obowiązek być w zgodzie z celami i perspektywami przedsiębiorstwa, ale komponując ją nie można nie pamiętać o konstruktywnym rozszerzaniu aspiracji zatrudnionych (Amstrong, 1996: 220).

Teoria drogi do celu (path-goal theory) przedstawia bardzo dokładnie relację między udziałem pracownika w działaniu przedsiębiorstwa, a sposobem jego wynagradzania. Zgodnie $\mathrm{z}$ nią fundamentalną przesłanką efektywnego działania człowieka jest ewidentne, niczym niezakłócone postrzeganie przez niego zależności występującej między uzyskaniem danego wyniku $\mathrm{w}$ pracy a następującym po nim odniesieniem korzyści $\mathrm{w}$ formie pensji. Obowiązki w pracy uznawane są przez pracownika jako narzędzie, droga do celu, którym zazwyczaj są pieniądze. W rozwiniętej postaci opisanego wyżej modelu motywo- wania zadaniowego bierze się pod uwagę znacznie większą liczbe faktorów i warunków do spełnienia (Adamiec i Kożusznik, 2000, s. 140-142):

1. Warunek P-A - pracownik musi być zdolny do wykonania działania A.

Oznacza to, że musi dysponować adekwatnymi kompetencjami, kwalifikacjami i możliwościami, niezbędnymi do pracy na danym stanowisku. Pracownik charakteryzujący się wysokim poziomem wymienionych wcześniej cech nie może realizować obowiązków poniżej swych umiejętności; przy czym przypisane mu działania nie mogą znacznie przewyższać jego kwalifikacji. Jego obowiązki powinny być tak łatwe, by nie było problemów z prawidłowym ich wykonaniem, a jednocześnie tak trudne, by angażowały, powodowały wyzwanie, mobilizowały do pracy, a ponadto miały - odpowiednio do sukcesu i porażki pozytywne bądź negatywne oddziaływanie na samoocenę.

2. Warunek A-E - musi istnieć związek między wykonaniem działań A a ich oczekiwanym efektem E.

Niespełnienie drugiej przesłanki sprawia, że pracownik staje się bezsilny i zniechęcony, a w wyniku tego oddala się realnie i duchowo od swych zadań. Należy więc pamiętać, by pracownik zapoznał się z kryteriami osiągnięcia, pomiaru i wartościowania spodziewanego wyniku oraz jego oceny.

3. Warunek E-C - musi istnieć związek między efektem $\mathrm{E}$ a osiągnięciem własnego celu C.

Rolę elementu C odgrywa zazwyczaj wynagrodzenie. Toteż spełnienie trzeciego warunku prowadzi do wzrostu zaangażowania oraz zadowolenia osoby motywowanej. Ponadto pracownik trwale asocjuje związek między E a C dzięki czemu osiągnięcie ich obu jest dla niego tak samo istotne. Najpopularniejszą formą wynagrodzenia są pieniądze, jednakże zdarza się, że pracownik liczy na coś innego, a w tej sytuacji wynagrodzenie w postaci pieniężnej charakteryzować się będzie niską wartością motywacyjną, gdyż rozbiega się z jego preferencjami i przewidywaniami. 


\section{Motywacja i zmienne poboczne - ujęcie empiryczne}

$\mathrm{Na}$ podstawie materiału faktograficznego w artykule zostaną przedstawione najistotniejsze statystyki odnoszące się do wszystkich pytań zawartych w kwestionariuszu ankiety. Pierwsze pytanie w kwestionariuszu ankiety dotyczyło własnego wpływu na karierę. Wyniki przedstawione zostały w tabeli 2.

Tabela 2. Postrzeganie wpływu na swoją karierę $(w \%)$

\begin{tabular}{|l|c|c|c|}
\hline \multicolumn{1}{|c|}{ Stwierdzenie } & $\begin{array}{c}\text { Cała } \\
\text { próba }\end{array}$ & $\begin{array}{c}\text { Kobie- } \\
\text { ty }\end{array}$ & $\begin{array}{c}\text { Męż- } \\
\text { czyźni }\end{array}$ \\
\hline $\begin{array}{l}\text { Moja kariera zawodo- } \\
\text { wa zależy ode mnie }\end{array}$ & 92,5 & 93,5 & 90,9 \\
\hline $\begin{array}{l}\text { Nie mam wpływu na } \\
\text { moją karierę }\end{array}$ & 7,5 & 6,5 & 9,1 \\
\hline
\end{tabular}

Źródło: opracowanie własne.

Prawie 92,5\% wszystkich respondentów było zdania, że ich kariera zawodowa zależy wyłącznie od nich samych. Jest to bardzo pozytywny wynik, gdyż świadczy o przekonaniu prawie wszystkich studentów o wewnątrzsterowności w kształtowaniu swojej kariery. Ponadto można zaobserwować, że więcej kobiet sądzi, iż ich kariera zależy praktycznie od nich samych. Świadczyć to może o tym, iż są one bardziej przebojowe i pewne siebie aniżeli ankietowani mężczyźni. Istotność wpływu czynników egzogenicznych na rozwój kariery prezentuje tabela 3 .

$\mathrm{Z}$ przeprowadzonych badań wynika, że w badanej próbie za najważniejszy determinant zewnętrzny wpływający na rozwój kariery uważa się znajomości, natomiast za najmniej istotny - presję i oczekiwania najbliższych względem nas. Wynik ten może być spowodowany tym, że od dłuższego czasu nieprzerwanie panuje społeczne przekonanie, że nie tyle wyuczony zawód czy zdobyte w trakcie edukacji kwalifikacje, ile właśnie odpowiednie układy i znajomości, wywierają decydujący wpływ na znalezienie pracy i przebieg kariery. Najbardziej zróżnicowane były odpowiedzi dotyczące wpływu przypadku na karierę (tabela 4). Jedynym czynnikiem charakteryzującym się słabą, lecz dodatnią, prawostronną asymetrią jest presja i oczekiwania najbliższych wobec nas (czyli średnia odpowiedź znajduje się na prawo od odpowiedzi dominującej w odległości prawie 0,3 odchylenia standardowego). Z kolei wyraźna lewostronna, ujemna asymetria charakteryzuje znajomości $\left(\gamma_{3}=-0,701\right)$. Wszystkie badane determinanty o charakterze egzogenicznym maja rozkład bardziej spłaszczony od normalnego (platokurtyczny), co świadczy o dużym zróżnicowaniu odpowiedzi $\left(\gamma_{4}<0\right)$.

Zarówno kobiety, jak i mężczyźni uznali znajomości za najistotniejszy czynnik zewnętrzny wpływający na rozwój ich kariery, zaś presję i oczekiwania najbliższych za determinant najmniej istotny. Najbardziej zróżnicowane w obu grupach były natomiast odpowiedzi dotyczące istotności przypadku.

Natomiast ocenę znaczenia „twardych" kompetencji dla rozwoju kariery zawodowej zaprezentowano w tabeli 5.

Za najważniejsze „twarde” kompetencje wpływające na rozwój kariery respondenci uznali, średnio w całej próbie, znajomość języków obcych, natomiast za najmniej ważną: wysoką średnią z toku studiów, co więcej, odpowiedzi dotyczące właśnie

Tabela 3. Znaczenie poszczególnych czynników zewnętrznych dla rozwoju kariery zawodowej w całej próbie

\begin{tabular}{|c|c|c|c|c|c|c|}
\hline Czynniki zewnętrzne & 璦 & 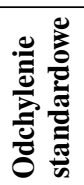 & 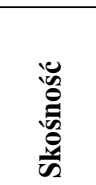 & 遏 & 䒠 & 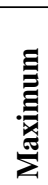 \\
\hline Sytuacja gospodarcza & 3,31 & 0,586 & $-0,186$ & $-0,588$ & 2 & 4 \\
\hline Presja i oczekiwania najbliższych & 2,48 & 0,787 & 0,291 & $-0,355$ & 1 & 4 \\
\hline Znajomości & 3,48 & 0,602 & $-0,701$ & $-0,451$ & 2 & 4 \\
\hline Przypadek & 2,62 & 0,824 & 0,114 & $-0,612$ & 1 & 4 \\
\hline
\end{tabular}

Źródło: opracowanie własne. 
Tabela 4. Różnice pomiędzy kobietami a mężczyznami w zakresie postrzegania istotności poszczególnych czynników zewnętrznych

\begin{tabular}{|l|c|c|c|c|}
\hline \multirow{2}{*}{ Czynniki zewnętrzne } & \multicolumn{2}{c|}{ Kobiety } & \multicolumn{2}{c|}{ Mężczyźni } \\
\cline { 2 - 5 } & średnia & $\begin{array}{c}\text { odchylenie } \\
\text { standardowe }\end{array}$ & średnia & $\begin{array}{c}\text { odchylenie } \\
\text { standardowe }\end{array}$ \\
\hline Sytuacja gospodarcza & 3,27 & 0,601 & 3,36 & 0,568 \\
\hline Presja i oczekiwania najbliższych & 2,51 & 0,738 & 2,45 & 0,855 \\
\hline Znajomości & 3,44 & 0,642 & 3,53 & 0,546 \\
\hline Przypadek & 2,59 & 0,796 & 2,66 & 0,867 \\
\hline
\end{tabular}

Źródło: opracowanie własne.

Tabela 5. Statystyki opisowe dla znaczenia poszczególnych „twardych” kompetencji dla rozwoju kariery zawodowej w całej próbie

\begin{tabular}{|c|c|c|c|c|c|c|}
\hline „Twarde” kompetencje & 尝 & 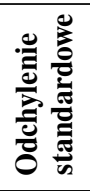 & 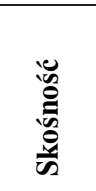 & 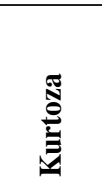 & 㤩 & 志 \\
\hline Znajomość języków obcych & 3,76 & 0,448 & $-1,566$ & 1,280 & 2 & 4 \\
\hline Odbyte praktyki & 3,50 & 0,602 & $-0,771$ & $-0,362$ & 2 & 4 \\
\hline Wyższe wykształcenie i kwalifikacje & 3,63 & 0,588 & $-1,337$ & 0,802 & 2 & 4 \\
\hline Wysoka średnia z toku studiów & 2,45 & 0,925 & 0,100 & $-0,804$ & 1 & 4 \\
\hline
\end{tabular}

Źródło: opracowanie własne.

jej, były tymi najbardziej zróżnicowanymi $(\delta=0,925)$ i charakteryzującymi się dodatnią, prawostronną, lecz bardzo słabą asymetrią $\left(\gamma_{3}=0,100\right)$. Z kolei bardzo silna lewostronna, ujemna asymetria charakteryzuje znajomość języków obcych $\left(\gamma_{3}=-1,566\right)$ oraz wyższe wykształcenie i kwalifikacje $\left(\gamma_{3}=-1,337\right)$. Rozkład odpowiedzi odnośnie do istotności znajomości języków obcych jest leptokurtyczny - wysmukły i charakteryzuje się małym zróżnicowaniem odpowiedzi $\left(\gamma_{4}=1,280\right)$, natomiast odbyte praktyki $\left(\gamma_{4}=-0,362\right)$ oraz wysoka średnia $\mathrm{z}$ toku studiów $\left(\gamma_{4}=-0,804\right)$ mają rozkład bardziej spłaszczony od normalnego (platokurtyczny), co ewidentnie świadczy o wyraźnym zróżnicowaniu odpowiedzi na ich temat. Istotność wysokości średniej $\mathrm{z}$ toku studiów i jej wpływu na znalezienie pracy jest tematem sporów, co znalazło odzwierciedlenie w wyniku przeprowadzonej analizy.

W celu zbadania, czy zmienne mają rozkład normalny przeprowadzono test Kolmogorowa-Smirnowa (tabela 6).
Tabela 6. Analiza normalności rozkładów zmiennych związanych z "twardymi” kompetencjami test Kolmogorowa-Smirnowa

\begin{tabular}{|l|l|}
\hline \multicolumn{1}{|c|}{ „Twarde” kompetencje } & \multicolumn{1}{c|}{ Cała próba } \\
\hline Znajomość języków obcych & $\mathrm{Z}=4,971^{* * *}$ \\
\hline Odbyte praktyki & $\mathrm{Z}=3,686^{* * *}$ \\
\hline $\begin{array}{l}\text { Wyższe wykształcenie i kwali- } \\
\text { fikacje }\end{array}$ & $\mathrm{Z}=4,391^{* * *}$ \\
\hline Wysoka średnia z toku studiów & $\mathrm{Z}=2,358^{* * *}$ \\
\hline
\end{tabular} $\begin{aligned} & { }^{* * *} \mathrm{p}<0,001 \text { : Korelacja jest istotna na poziomie } \\
& 0,001 \text { (dwustronnie). }\end{aligned}$

Źródło: opracowanie własne.

Po przeprowadzeniu testu Kołmogorowa-Smirnowa okazało się, że należy odrzucić hipotezę o normalności rozkładów analizowanych zmiennych. Właściwości omawianych rozkładów wskazują, iż do analizy zmiennych zastosowane mogą zostać jedynie testy nieparametryczne (używane właśnie wtedy, gdy rozkłady nie mają charakteru normalnego). 
Analiza przeprowadzona zostanie przy użyciu testu nieparametrycznego - testu U Manna-Whitneya (tabela 7).

Test U Manna-Whitneya wskazał na występowanie istotnej statystycznie różnicy na poziomie 0,05 , między średnimi w grupie kobiet i mężczyzn w przypadku znajomości języków obcych, przy czym średnia w grupie kobiet $(3,86)$ jest wyższa niż w grupie mężczyzn $(3,64)$, co potwierdza drugą, postawioną $\mathrm{w}$ pracy hipoteze cząstkową, iż istnieją różnice, w grupie kobiet i mężczyzn, w postrzeganiu istotności znajomości języków obcych dla rozwoju kariery zawodowej. Taki wynik spowodowany może być przez tym, że to właśnie kobiety zazwyczaj pracują w zawodach, w których znajomość języków obcych

Tabela 7. Testowanie istotności - test U Manna-Whitneya

\begin{tabular}{|c|c|c|c|c|c|}
\hline \multirow[b]{2}{*}{ „Twarde” kompetencje } & \multicolumn{2}{|c|}{ Kobiety } & \multicolumn{2}{|c|}{ Mężczyźni } & \multirow[b]{2}{*}{ Test } \\
\hline & 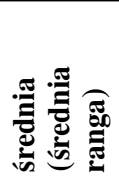 & 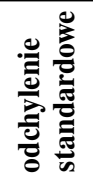 & 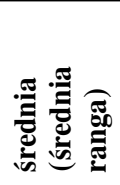 & 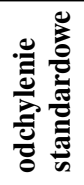 & \\
\hline Znajomość języków obcych & $\begin{array}{c}3,86 \\
(60,21)\end{array}$ & 0,353 & $\begin{array}{c}3,64 \\
(49,18)\end{array}$ & 0,529 & $Z=1183,5^{*}$ \\
\hline Odbyte praktyki & $\begin{array}{c}3,51 \\
(55,72)\end{array}$ & 0,592 & $\begin{array}{c}3,49 \\
(55,20)\end{array}$ & 0,621 & $Z=1466,5$ \\
\hline Wyższe wykształcenie i kwalifikacje & $\begin{array}{c}3,70 \\
(57,87)\end{array}$ & 0,496 & $\begin{array}{c}3,53 \\
(52,33)\end{array}$ & 0,687 & $Z=1331,5$ \\
\hline Wysoka średnia z toku studiów & $\begin{array}{c}2,52 \\
(57,67)\end{array}$ & 0,859 & $\begin{array}{c}2,36 \\
(52,60)\end{array}$ & 1,009 & $Z=1344,0$ \\
\hline
\end{tabular}

* $\mathrm{p}<0,05$ : Korelacja jest istotna na poziomie 0,05 (dwustronnie).

Źródło: opracowanie własne.

Tabela 8. Znaczenie poszczególnych „miękkich” kompetencji dla rozwoju kariery zawodowej w całej próbie

\begin{tabular}{|c|c|c|c|c|c|c|}
\hline „Miękkie” kompetencje & & 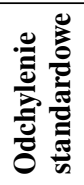 & 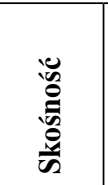 & 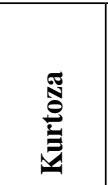 & 声 & 䒠 \\
\hline Automotywacja & 3,50 & 0,520 & $-0,199$ & $-1,513$ & 2 & 4 \\
\hline Wiara w siebie & 3,58 & 0,565 & $-0,952$ & $-0,085$ & 2 & 4 \\
\hline Inteligencja & 3,63 & 0,556 & $-1,173$ & 0,417 & 2 & 4 \\
\hline Przedsiębiorczość, zaradność, spryt & 3,78 & 0,457 & $-1,954$ & 3,101 & 2 & 4 \\
\hline Chęć ciągłego uczenia się & 3,19 & 0,672 & $-0,424$ & 0,017 & 1 & 4 \\
\hline Zaangażowanie w wykonywane czynności & 3,59 & 0,565 & $-0,980$ & $-0,025$ & 2 & 4 \\
\hline Gotowość do podejmowania ryzyka & 3,38 & 0,680 & $-0,643$ & $-0,668$ & 2 & 4 \\
\hline Odporność na stres & 3,57 & 0,629 & $-1,174$ & 0,299 & 2 & 4 \\
\hline Umiejętność chwytania nadarzających się okazji & 3,53 & 0,586 & $-0,828$ & $-0,283$ & 2 & 4 \\
\hline Skłonność do wyrzeczeń i poświęceń & 3,27 & 0,676 & $-0,379$ & $-0,796$ & 2 & 4 \\
\hline Umiejętność skutecznej komunikacji & 3,57 & 0,566 & $-1,219$ & 2,266 & 1 & 4 \\
\hline
\end{tabular}

Źródło: opracowanie własne. 
Tabela 9. Różnice pomiędzy kobietami a mężczyznami w zakresie postrzegania istotności poszczególnych „miękkich” kompetencji

\begin{tabular}{|l|c|c|c|c|}
\hline \multirow{2}{*}{ „Miękkie” kompetencje } & \multicolumn{2}{|c|}{ Kobiety } & \multicolumn{2}{c|}{ Mężczyźni } \\
\cline { 2 - 5 } & średnia & $\begin{array}{c}\text { odchylenie } \\
\text { standardowe }\end{array}$ & średnia & $\begin{array}{c}\text { odchylenie } \\
\text { standardowe }\end{array}$ \\
\hline Automotywacja & 3,51 & 0,504 & 3,49 & 0,547 \\
\hline Wiara w siebie & 3,63 & 0,485 & 3,51 & 0,655 \\
\hline Inteligencja & 3,67 & 0,508 & 3,57 & 0,617 \\
\hline Przedsiębiorczość, zaradność, spryt & 3,76 & 0,465 & 3,81 & 0,449 \\
\hline Chęć ciągłego uczenia się & 3,21 & 0,656 & 3,15 & 0,698 \\
\hline Zaangażowanie w wykonywane czynności & 3,60 & 0,557 & 3,57 & 0,580 \\
\hline Gotowość do podejmowania ryzyka & 3,39 & 0,686 & 3,37 & 0,679 \\
\hline Odporność na stres & 3,61 & 0,583 & 3,51 & 0,688 \\
\hline Umiejętność chwytania nadarzających się okazji & 3,55 & 0,592 & 3,51 & 0,585 \\
\hline Skłonność do wyrzeczeń i poświęceń & 3,35 & 0,630 & 3,15 & 0,722 \\
\hline Umiejętność skutecznej komunikacji & 3,65 & 0,481 & 3,47 & 0,654 \\
\hline
\end{tabular}

Źródło: opracowanie własne.

odgrywa kluczową rolę, takich jak asystentka czy sekretarka.

Natomiast ocenę znaczenia „miękkich” kompetencji dla rozwoju kariery zawodowej przedstawia tabela 8.

Przeciętnie w całej próbie za najważniejszą „miękką” kompetencję wpływającą na rozwój kariery zawodowej uznano przedsiębiorczość, zaradność oraz spryt, natomiast za najmniej istotną - chęć ciągłego uczenia się. Najbardziej zróżnicowanymi odpowiedziami były te, które dotyczyły istotności gotowości do podejmowania ryzyka $(\delta=0,680)$, skłonności do wyrzeczeń i poświęceń $(\delta=0,676)$ oraz chęci ciągłego uczenia się $(\delta=0,672)$. Z kolei odpowiedzi charakteryzujące się najmniejszym zróżnicowaniem dotyczyły przedsiębiorczości, zaradności oraz sprytu $(\delta=0,457)$, i one także cechowały się bardzo silną ujemną, lewostronną asymetrią $\left(\gamma_{3}=-1,954\right)$. Rozkład odpowiedzi odnośnie do istotności przedsiębiorczości, zaradności oraz sprytu jest leptokurtyczny - wysmukły - i charakteryzuje się bardzo małym zróżnicowaniem odpowiedzi $\left(\gamma_{4}=3,101\right)$, natomiast automotywacja $\left(\gamma_{4}=-1,513\right)$ ma rozkład bardziej spłaszczony od normalnego (platokurtyczny), co świadczy o wyraźnym zróżnicowaniu odpowiedzi na jej temat.

Zarówno kobiety, jak i mężczyźni uznali średnio za najważniejsze $\mathrm{z}$,miękkich” kompetencji przedsiębiorczość, zaradczość oraz spryt (odpowiednio kobiety: 3,76 oraz mężczyźni: 3,81 ) (tabela 8). Z kolei za najmniej istotną w rozwoju kariery zawodowej kobiety uważają chęć ciągłego uczenia się $(3,21)$, natomiast mężczyźni ex aequo chęć ciągłego uczenia się oraz skłonność do wyrzeczeń i poświęceń $(3,15)$. Odpowiedzi wskazują na panujące wśród młodzieży przekonanie, iż jeżeli chce się osiągnąć obrany cel, należy być zaradnym, nie zniechęcać się małymi niepowodzeniami, trzeba także wykazywać się szybkim reagowaniem na zmiany pojawiające się $\mathrm{w}$ otoczeniu, być sprytnym i przedsiębiorczym. Najbardziej zróżnicowane w grupie kobiet były odpowiedzi dotyczące gotowości do podejmowania ryzyka $(\delta=0,686)$, natomiast $w$ grupie mężczyzn były te, które dotyczyły skłonności do wyrzeczeń i poświęceń $(\delta=0,722)$.

$\mathrm{Z}$ kolei ocenę istotności poziomu własnej motywacji do działania w rozpoczęciu kariery zawodowej została zawarta w tabeli 10.

Przeciętnie w całej próbie osobista motywacja do działania jest istotna w rozpoczęciu kariery zawodowej $(3,46)$. Odpowiedzi różnią się jednak od średniej przeciętnie o 0,631. Rozkład odpowiedzi cechuje się silną ujemną, lewostronną asymetrią $\left(\gamma_{3}=-1,202\right)$. Rozkład odpowiedzi odnośnie do istotności motywacji jest leptokurtyczny - wysmukły - charakteryzuje się bardzo małym zróżnicowaniem odpowiedzi $\left(\gamma_{4}=2,420\right)$. Odpowiedzi udzielone 
Tabela 10. Statystyki opisowe dla istotności motywacji do działania w rozpoczęciu kariery zawodowej w całej próbie

\begin{tabular}{|c|c|c|c|c|c|c|}
\hline Statystyki opisowe & 嵒 & 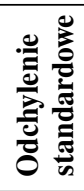 & 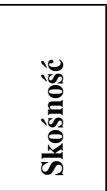 & & 䒠 & 志 \\
\hline $\begin{array}{l}\text { Jak oceniasz istotność swojej motywacji do } \\
\text { działania w rozpoczęciu kariery zawodowej? }\end{array}$ & 3,46 & 0,631 & $-1,202$ & 2,420 & 1 & 4 \\
\hline
\end{tabular}

Źródło: opracowanie własne.

Tabela 11. Różnice między kobietami a mężczyznami w zakresie postrzegania istotności motywacji do działania w rozpoczęciu kariery zawodowej

\begin{tabular}{|c|c|c|c|c|}
\hline \multirow{2}{*}{ Statystyki opisowe } & \multicolumn{2}{|c|}{ Kobiety } & \multicolumn{2}{c|}{ Mężczyźni } \\
\cline { 2 - 5 } & średnia & $\begin{array}{c}\text { odchylenie } \\
\text { standardowe }\end{array}$ & średnia & $\begin{array}{c}\text { odchylenie } \\
\text { standardowe }\end{array}$ \\
\hline $\begin{array}{l}\text { Jak oceniasz istotność swojej motywacji do } \\
\text { działania w rozpoczęciu kariery zawodowej? }\end{array}$ & 3,48 & 0,618 & 3,45 & 0,653 \\
\hline
\end{tabular}

Źródło: opracowanie własne.

Tabela 12. Statystyki opisowe dla oceny poziomu motywacji do rozpoczęcia pracy zawodowej w całej próbie

\begin{tabular}{|c|c|c|c|c|c|c|}
\hline Statystyki opisowe & & 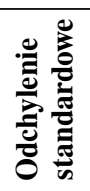 & 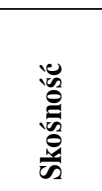 & 䒿 & 罣 & 当 \\
\hline $\begin{array}{l}\text { Jak oceniasz poziom swojej motywacji do rozpo- } \\
\text { częcia pracy zawodowej? }\end{array}$ & 3,05 & 0,734 & $-0,638$ & 0,623 & 1 & 4 \\
\hline
\end{tabular}

Źródło: opracowanie własne.

przez respondentów rozrzucone były po całej skali $($ Min $=1$, Max $=4)$, czyli były bardzo zróżnicowane.

Średnia ocena istotności własnej motywacji do działania w rozpoczęciu kariery zawodowej jest w przybliżeniu taka sama dla kobiet i mężczyzn (odpowiednio: 3,48 i 3,45) (tabela 11). Zróżnicowanie odpowiedzi jest jednak większe wśród grupy mężczyzn o 0,035 .

$\mathrm{Z}$ kolei ocenę poziomu motywacji do rozpoczęcia pracy zawodowej zaprezentowano w tabeli 12.

Średnio w całej próbie poziom własnej motywacji do rozpoczęcia pracy zawodowej oceniany jest jako „raczej wysoki”. Odpowiedzi różnią się jednak od średniej przeciętnie o 0,734. Rozkład odpowiedzi cechuje się wyraźną, ujemną, lewostronną asymetrią $\left(\gamma_{3}=-0,638\right)$. Rozkład odpowiedzi odnośnie do poziomu własnej motywacji jest leptokurtyczny - wysmukły - charakteryzuje się małym zróżnicowaniem odpowiedzi $\left(\gamma_{4}=0,623\right)$. Odpowiedzi udzielone przez respondentów rozrzucone były po całej skali $(\operatorname{Min}=1$, Max $=4)$.

Srednia ocena poziomu własnej motywacji do rozpoczęcia pracy zawodowej jest wyższa dla kobiet $(3,14)$ niż dla mężczyzn $(2,91)$, co potwierdza pierwszą, postawioną w pracy hipotezę cząstkową, iż istnieją różnice między oceną poziomu własnej motywacji do rozpoczęcia pracy zawodowej w grupie kobiet i mężczyzn (tabela 13). Zróżnicowanie odpowiedzi jest jednak bardzo zbliżone w obu grupach - odpowiednio dla kobiet wynosi: 0,715, zaś dla mężczyzn: 0,747.

Kolejne pytanie w kwestionariuszu ankiety dotyczyło posiadania sprecyzowanych planów zawodowych na przyszłość. 
Tabela 13. Różnice między kobietami a mężczyznami w zakresie oceny poziomu motywacji do rozpoczęcia pracy zawodowej

\begin{tabular}{|c|c|c|c|c|}
\hline \multirow{2}{*}{ Statystyki opisowe } & \multicolumn{2}{|c|}{ Kobiety } & \multicolumn{2}{c|}{ Mężczyźni } \\
\cline { 2 - 5 } & średnia & $\begin{array}{c}\text { odchylenie } \\
\text { standardowe }\end{array}$ & średnia & $\begin{array}{c}\text { odchylenie } \\
\text { standardowe }\end{array}$ \\
\hline $\begin{array}{l}\text { Jak oceniasz poziom swojej motywacji do roz- } \\
\text { poczęcia pracy zawodowej? }\end{array}$ & 3,14 & 0,715 & 2,91 & 0,747 \\
\hline
\end{tabular}

Źródło: opracowanie własne.

Tabela 14. Posiadanie sprecyzowanych planów zawodowych na przyszłość (w \%)

\begin{tabular}{|l|c|c|c|}
\hline Czy masz już sprecyzowane plany zawodowe na przy- & Cała próba & Kobiety & Mężczyźni \\
\hline Zdecydowanie nie & 4,5 & 3,2 & 6,4 \\
\hline Raczej nie & 33,6 & 33,3 & 34,0 \\
\hline Raczej tak & 50,9 & 52,4 & 48,9 \\
\hline Zdecydowanie tak & 10,9 & 11,1 & 10,6 \\
\hline
\end{tabular}

Źródło: opracowanie własne.

Tabela 15. Posiadanie doświadczenia $w$ pracy ( $w \%)$

\begin{tabular}{|l|c|c|c|}
\hline \multicolumn{1}{|c|}{ Czy pracowałeś już? } & Cała próba & Kobiety & Mężczyźni \\
\hline Nie & 30,9 & 31,7 & 29,8 \\
\hline Tak & 69,1 & 68,3 & 70,2 \\
\hline
\end{tabular}

Źródło: opracowanie własne.

Tabela 16. Plany odnośnie do podjęcia pracy w najbliższym czasie ( $w$ \%)

\begin{tabular}{|l|c|c|c|}
\hline Czy planujesz w najbliższym czasie podjąć pracę? & Cała próba & Kobiety & Mężczyźni \\
\hline Zdecydowanie nie & 5,9 & 5,0 & 7,1 \\
\hline Raczej nie & 41,2 & 35,0 & 50,0 \\
\hline Raczej tak & 47,1 & 50,0 & 42,9 \\
\hline Zdecydowanie tak & 5,9 & 10,0 & 0,0 \\
\hline
\end{tabular}

Źródło: opracowanie własne.

Wyniki odpowiedzi na tak zadane pytanie przedstawione zostały w tabeli 14.

Co drugi respondent $(50,9 \%)$ stwierdził, że „raczej” ma już sprecyzowane plany zawodowe na przyszłość. Jeżeli zaś chodzi o podział na grupy płci, to o $3,5 \%$ więcej kobiet niż mężczyzn ma już sprecyzowane plany w tym zakresie. Nieznacznie (bo jedynie o $0,5 \%$ ) więcej kobiet ,zdecydowanie” ma już jasno określone plany zawodowe na przyszłość. Z kolei o prawie $3 \%$ więcej ankietowanych mężczyzn niż kobiet ,zdecydowanie" nie ma sprecyzowanych planów zawodowych na przyszłość.
Odpowiedzi na pytanie, czy osoby, które wzięły udział w niniejszym badaniu już kiedyś pracowały, dostarczy nam odpowiedź na kolejne pytanie zawarte w kwestionariuszu ankiety (tabela 15).

Odpowiedzi zarówno kobiet, jak i mężczyzn oscylują bardzo blisko tych samych wartości. Prawie $32 \%$ kobiet i co trzeci mężczyzna jeszcze nigdy nie pracowali, natomiast $68,3 \%$ kobiet i $70,2 \%$ mężczyzn już ma doświadczenie w miejscu pracy. $\mathrm{Z}$ kolei odpowiedzi na pytanie, czy respondenci planują w najbliższym czasie podjąć pracę, zostały zawarte w tabeli 16 . 


\begin{tabular}{|c|c|c|c|c|c|c|}
\hline Sposoby motywowania & 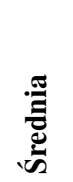 & 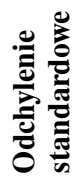 & 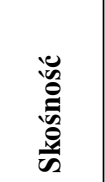 & 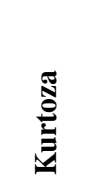 & 䒠 & 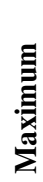 \\
\hline Otrzymywanie pochwał & 3,12 & 0,610 & $-0,063$ & $-0,299$ & 2 & 4 \\
\hline Awans & 3,63 & 0,610 & $-1,788$ & 3,837 & 1 & 4 \\
\hline $\begin{array}{l}\text { Wysokość wynagrodzenia proporcjonalna do wyko- } \\
\text { nanej pracy }\end{array}$ & 3,71 & 0,540 & $-2,222$ & 7,041 & 1 & 4 \\
\hline Dodatkowe gratyfikacje za ponadprzeciętne efekty & 3,61 & 0,567 & $-1,148$ & 0,374 & 2 & 4 \\
\hline Wysoki poziom stresu & 1,75 & 0,785 & 0,817 & 0,152 & 1 & 4 \\
\hline Lęk przed przełożonym & 1,47 & 0,757 & 1,608 & 2,071 & 1 & 4 \\
\hline
\end{tabular}

Źródło: opracowanie własne.

Prawie co druga ankietowana kobieta stwierdziła, że „raczej” planuje w najbliższym czasie podjąć pracę. Dokładnie tyle samo mężczyzn stwierdziło wprost przeciwnie, że „raczej” nie planuje podjąć pracy w najbliższym czasie. Jedynie liczba respondentów obu płci, którzy „zdecydowanie” nie planują podjąć pracy w najbliższym czasie różni się nieznacznie (bo jedynie o ok. 2\%).

Ocenę skuteczności poszczególnych sposobów motywowania przedstawiono w tabeli 17.

Za najskuteczniejszy sposób motywowania uznano średnio w całej próbie wysokość wynagrodzenia proporcjonalną do wykonywanej pracy $(3,71)$, natomiast za najmniej skuteczny: lęk przed przełożonym $(1,47)$ oraz wysoki poziom stresu $(1,75)$. Należy w tym miejscu zaznaczyć, że odpowiedzi dotyczące właśnie tych sposobów motywowania były najbardziej zróżnicowane (odpowiednio: $\delta=0,757$ oraz $\delta=0,785$ ). Stanowi to dowód na to, że jeżeli pracodawca pragnie mieć zmotywowanego do pracy podwładnego, to najgorsze, co mógłby w stosunku do niego zrobić, to straszyć go, karać, czy sprawiać, że ten odczuwałby lęk wobec swojego przełożonego. Wysokość wynagrodzenia proporcjonalna do wykonywanej pracy jest sposobem motywowania, którego rozkład odpowiedzi charakteryzuje się ujemną, lewostronną, lecz bardzo silną asymetria $\left(\gamma_{3}=-2,222\right)$. Z kolei także bardzo silną, lecz prawostronną, dodatnią asymetrią charakteryzuje się lęk przed przełożonym $\left(\gamma_{3}=1,608\right)$. Rozkład odpowiedzi dotyczących skuteczności w motywowaniu wysokości wynagrodzenia proporcjonalnej do wykonywanej pracy jest najbardziej leptokurtyczny - wysmukły, czyli cechuje się bardzo małym zróżnicowaniem odpowiedzi $\left(\gamma_{4}=7,041\right)$. Z kolei otrzymywanie pochwał od przełożonego $\left(\gamma_{4}=-0,299\right)$ jako jedyne ma rozkład bardziej spłaszczony od normalnego (platokurtyczny), co świadczy o dość wyraźnym zróżnicowaniu odpowiedzi na temat chwalenia pracownika.

W celu zbadania, czy zmienne mają rozkład normalny, przeprowadzono test Kolmogorowa-Smirnowa (tabela 18).

Tabela 18. Analiza normalności rozkładów zmiennych związanych ze sposobami motywowania test Kotmogorowa-Smirnowa

\begin{tabular}{|l|l|}
\hline \multicolumn{1}{|c|}{ Sposoby motywowania } & Cała próba \\
\hline Otrzymywanie pochwał & $\mathrm{Z}=2,850^{* * *}$ \\
\hline Awans & $\mathrm{Z}=3,548^{* * *}$ \\
\hline $\begin{array}{l}\text { Wysokość wynagrodzenia } \\
\text { proporcjonalna do wykonanej } \\
\text { pracy }\end{array}$ & $\mathrm{Z}=3,810^{* * *}$ \\
\hline $\begin{array}{l}\text { Dodatkowe gratyfikacje za } \\
\text { ponadprzeciętne efekty }\end{array}$ & $\mathrm{Z}=3,514^{* * *}$ \\
\hline Wysoki poziom stresu & $\mathrm{Z}=2,305^{* * *}$ \\
\hline Lęk przed przełożonym & $\mathrm{Z}=3,419^{* * *}$ \\
\hline
\end{tabular}

* $\mathrm{p}<0,001$ : korelacja jest istotna na poziomie 0,001 (dwustronnie)

Źródło: opracowanie własne.

Analiza przeprowadzona zostanie przy użyciu testu nieparametrycznego - testu U Manna-Whitneya, gdyż rozkłady zmiennych nie mają rozkładu normalnego (tabela 19). 


\begin{tabular}{|c|c|c|c|c|c|}
\hline \multirow[b]{2}{*}{ Sposoby motywowania } & \multicolumn{2}{|c|}{ Kobiety } & \multicolumn{2}{|c|}{ Mężczyźni } & \multirow[b]{2}{*}{ Test } \\
\hline & 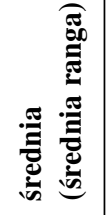 & 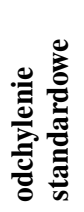 & 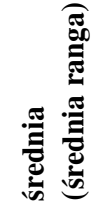 & 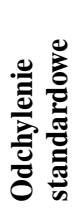 & \\
\hline Otrzymywanie pochwał & $\begin{array}{c}3,28 \\
(43,52)\end{array}$ & 0,591 & $\begin{array}{c}2,91 \\
(31,95)\end{array}$ & 0,579 & $Z=493,5^{*}$ \\
\hline Awans & $\begin{array}{c}3,72 \\
(40,52)\end{array}$ & 0,504 & $\begin{array}{c}3,50 \\
(34,61)\end{array}$ & 0,718 & $Z=579,5$ \\
\hline $\begin{array}{l}\text { Wysokość wynagrodzenia proporcjonalna do } \\
\text { wykonanej pracy }\end{array}$ & $\begin{array}{c}3,74 \\
(38,31)\end{array}$ & 0,445 & $\begin{array}{c}3,67 \\
(37,61)\end{array}$ & 0,645 & $Z=680,0$ \\
\hline $\begin{array}{l}\text { Dodatkowe gratyfikacje za ponadprzeciętne } \\
\text { efekty }\end{array}$ & $\begin{array}{c}3,72 \\
(41,49)\end{array}$ & 0,504 & $\begin{array}{c}3,47 \\
(33,31)\end{array}$ & 0,621 & $\mathrm{Z}=538,0(\mathrm{t})$ \\
\hline Wysoki poziom stresu & $\begin{array}{c}1,72 \\
(38,20)\end{array}$ & 0,734 & $\begin{array}{c}1,79 \\
(38,89)\end{array}$ & 0,857 & $Z=696,5$ \\
\hline Lęk przed przełożonym & $\begin{array}{c}1,40 \\
(37,92)\end{array}$ & 0,583 & $\begin{array}{c}1,58 \\
(39,26)\end{array}$ & 0,936 & $Z=684,5$ \\
\hline
\end{tabular}

* $\mathrm{p}<0,05$ : Korelacja jest istotna na poziomie 0,05 (dwustronnie).

(t) - tendencja

Źródło: opracowanie własne.

Test U Manna-Whitneya wskazał na występowanie istotnej statystycznie różnicy między średnimi odpowiedziami w grupie kobiet i mężczyzn w przypadku otrzymywania pochwał na poziomie istotności 0,05 , przy czym średnia w grupie kobiet $(3,28)$ jest wyższa niż $\mathrm{w}$ grupie mężczyzn $(2,91)$. Potwierdza to trzecią, postawiona w pracy hipotezę cząstkową, iż otrzymywanie pochwał nie jest tak samo skutecznym motywatorem zarówno dla kobiet, jak i dla mężczyzn. Wynik ten spowodowany może być przez to, że kobiety zazwyczaj lubią być chwalone i potrzebuja tego, a dzięki pochwałom czują, że ich praca jest doceniana i czują się zmotywowane do dalszej pracy. Zaobserwowano także zależność na poziomie tendencji statystycznej między płcią a dodatkowymi gratyfikacjami za ponadprzeciętne efekty (średnia odpowiedzi kobiet jest także wyższa niż średnia odpowiedzi mężczyzn), przy poziomie istotności $\mathrm{p}=0,053$ (więc prawie 0,05 ). Jeżeli więc pracodawca pragnie zatrudniać zmotywowanego pracownika, to musi pamiętać, że wynagrodzenie jest dla większości pracowników (niezależnie od płci) najsilniejszym motywatorem.
Informacje na temat czy respondenci mają inne doświadczenie niż obowiązkowe praktyki studenckie, dostarczyły odpowiedzi na kolejne pytanie zawarte w kwestionariuszu ankiety (tabela 20).

Tabela 20. Posiadanie doświadczenia innego niż praktyki studenckie ( $w$ \%)

\begin{tabular}{|c|c|c|c|}
\hline $\begin{array}{l}\text { Czy posiadasz doświadcze- } \\
\text { nie inne niż obowiązkowe } \\
\text { praktyki studenckie? }\end{array}$ & 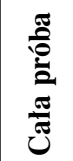 & $\frac{\overrightarrow{0}}{\stackrel{0}{0}}$ & 忽 \\
\hline $\mathrm{Nie}$ & 34,3 & 37,7 & 29,8 \\
\hline Tak & 65,7 & 62,3 & 70 , \\
\hline
\end{tabular}

Źródło: opracowanie własne.

Ponad $34 \%$ całej badanej próby studentów nie ma innego, poza obowiązkowym, doświadczenia zdobytego podczas praktyk studenckich. Jednakże ponad $2 / 5$ ankietowanych kobiet oraz co 7 z 10 ankietowanych mężczyzn było zdania, że ma doświadczenie inne niż obowiązkowe praktyki studenckie. Jest to bardzo pozytywny wynik, gdyż może on świadczyć o chęci do zdobywania przez 
młodych ludzi doświadczenia jeszcze podczas studiów, by po ich ukończeniu mieć lepszą pozycję na rynku pracy.

Kolejne pytanie zawarte w kwestionariuszu ankiety dotyczyło z kolei uczestnictwa w najbliższym czasie w kursach zawodowych, szkoleniach czy innych przygotowaniach merytorycznych, które potencjalnie mogą okazać się pomocne w zaistnieniu na rynku pracy. Wyniki przedstawione zostały w tabeli 21. mogą wesprzeć ich wejście na rynek pracy.

W kolejnym pytaniu respondenci zostali poproszeni o określenie, co według nich kryje się pod pojęciem „kariera”. Wyniki uzyskanych odpowiedzi przedstawia tabela 22.

Bardzo pozytywnym wynikiem analizy niniejszego pytania jest fakt, że znikoma liczba mężczyzn $(2,1 \%)$ oraz żadna $\mathrm{z}$ kobiet uczestniczących w badaniu, nie postrzega

Tabela 21. Posiadanie planów dotyczących podjęcia działań pomocnych w zaistnieniu na rynku pracy $(w \%)$

\begin{tabular}{|l|c|c|c|}
\hline $\begin{array}{c}\text { Czy rozważasz w najbliższym czasie podjęcie działań, które } \\
\text { potencjalnie mogą pomóc Ci zaistnieć na rynku pracy? }\end{array}$ & $\begin{array}{c}\text { Cała } \\
\text { próba }\end{array}$ & Kobiety & Mężczyźni \\
\hline Zdecydowanie nie & 0,0 & 0,0 & 0,0 \\
\hline Raczej nie & 23,6 & 27,0 & 19,1 \\
\hline Raczej tak & 52,7 & 47,6 & 59,6 \\
\hline Zdecydowanie tak & 23,6 & 25,4 & 21,3 \\
\hline
\end{tabular}

Źródło: opracowanie własne.

Tabela 22. Rozumienie pojęcia kariera (w \%)

\begin{tabular}{|l|c|c|c|}
\hline \multicolumn{1}{|c|}{ Co według Ciebie kryje się pod pojęciem kariera? } & Cała próba & Kobiety & Mężczyźni \\
\hline $\begin{array}{l}\text { Rozwój, zdobywanie profesjonalnych kompetencji i samo- } \\
\text { realizacja }\end{array}$ & 45,0 & 43,5 & 46,8 \\
\hline Osiągnięcie wysokiego stanowiska kierowniczego & 17,4 & 17,7 & 17,0 \\
\hline Uznanie i prestiż wśród znajomych & 0,9 & 0,0 & 2,1 \\
\hline Wartości ekonomiczne i niezależność finansowa & 36,7 & 38,7 & 34,0 \\
\hline
\end{tabular}

Źródło: opracowanie własne.

Zadowalającym wynikiem analizy jest fakt, że żadna osoba $\mathrm{z}$ badanej próby nie stwierdziła, iż ,zdecydowanie” nie zamierza podejmować żadnych działań ułatwiających zaistnienie na rynku pracy. $\mathrm{Z}$ kolei istotna różnica płci występuje przy odpowiedzi „raczej nie” - o 8\% więcej kobiet niż mężczyzn zaznaczyło w ankiecie tę odpowiedź. Natomiast prawie 3/5 mężczyzn „raczej” planuje udział w kursach lub innych działaniach, wpływających na zaistnienie na rynku pracy, przy prawie połowie ankietowanych kobiet, które zaznaczyły tę odpowiedź. Ponad 1/5 zarówno respondentek, jak i respondentów „zdecydowanie” rozważa w najbliższym czasie uczestnictwo w kursach lub innych przygotowaniach merytorycznych, które kariery jako uznania czy prestiżu, a zatem można przypuszczać, że wszelkie starania czynione przez nich w kierunku jej rozpoczęcia, kierowane są w celu osiągnięcia ich własnego dobra, a nie w celu ,pokazania się", wywyższania i bycia lepszym od swoich znajomych. Najwięcej ankietowanych kobiet $(43,5 \%)$ oraz respondentów $(46,8 \%)$ postrzega karierę jako rozwój, zdobywanie profesjonalnych kompetencji i samorealizację, a na drugim miejscu plasuje się postrzeganie kariery przez pryzmat wartości ekonomicznych i niezależności finansowej $(38,7 \%$ kobiet oraz 34\% mężczyzn). Ponad $17 \%$ wszystkich respondentów uważa, że wyznacznikiem kariery jest osiągnięcie wysokiego stanowiska kierowniczego. Ocena istotności poszczególnych 


\begin{tabular}{|c|c|c|c|c|c|c|}
\hline Czynniki & & 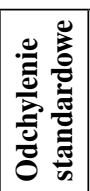 & 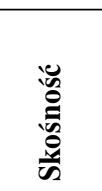 & 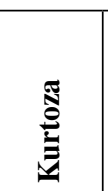 & 䒠 & 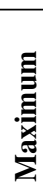 \\
\hline Samorealizacja & 3,25 & 0,627 & $-0,476$ & 0,528 & 1 & 4 \\
\hline $\begin{array}{l}\text { Wyzwania i działania wymagające twórczości i ini- } \\
\text { cjatywy }\end{array}$ & 3,06 & 0,705 & $-0,401$ & 0,098 & 1 & 4 \\
\hline Samodzielnie stawiane cele & 3,11 & 0,668 & $-0,315$ & $-0,029$ & 1 & 4 \\
\hline Odczuwanie sensu działania & 3,54 & 0,585 & $-0,842$ & $-0,261$ & 2 & 4 \\
\hline Równowaga między życiem osobistym a zawodowym & 3,55 & 0,686 & $-1,209$ & 0,150 & 2 & 4 \\
\hline Zapewnienie bezpieczeństwa socjalnego & 3,44 & 0,671 & $-0,970$ & 0,586 & 1 & 4 \\
\hline
\end{tabular}

Źródło: opracowanie własne.

czynników w pracy zaprezentowana jest w tabeli 23.

Za najistotniejsze czynniki w pracy uznano średnio w całej próbie równowagę między życiem osobistym a zawodowym $(3,55)$ oraz odczuwanie sensu działania $(3,54)$, a zaraz za nimi zapewnienie bezpieczeństwa socjalnego $(3,44)$. Świadczyć to może o tym, że obecnie nic nie jest tak ważne dla młodych ludzi jak możliwość godzenia dwóch kluczowych sfer życia ludzkiego (pracy i domu). Wiedząc o tym, pracodawcy powinni przestrzegać zasad CSR (corporate social resposibility). Mając na uwadze zróżnicowanie udzielanych odpowiedzi, to w najwyższym stopniu dotyczy to wyzwań i działań wymagających twórczości i inicjatywy $(\delta=0,705)$ oraz równowagi między życiem osobistym a zawodowym $(\delta=0,686)$. Rozkłady odpowiedzi dotyczących wszystkich czynników charakteryzują się ujemną, lewostronną asymetrią, a najsilniejsza dotyczy równowagi między życiem osobistym a zawodowym $\left(\gamma_{3}=-1,209\right)$. Rozkład odpowiedzi dotyczących zapewnienia bezpieczeństwa socjalnego jest najbardziej leptokurtyczny - wysmukły, czyli cechuje się małym zróżnicowaniem odpowiedzi $\left(\gamma_{4}=0,586\right)$, natomiast odczuwanie sensu działania $\left(\gamma_{4}=-0,261\right)$ ma rozkład najbardziej spłaszczony w stosunku do rozkładu normalnego (jest platokurtyczny), co świadczy o dość wyraźnym zróżnicowaniu odpowiedzi na temat potrzeby odczuwania sensu wykonywanych działań.

Płeć nie odgrywa większej roli w postrzeganiu istotności zawartych czynników występujących w pracy (tabela 24).

Tabela 24. Różnice między kobietami a mężczyznami w zakresie postrzegania istotności poszczególnych czynników w pracy

\begin{tabular}{|l|c|c|c|c|}
\hline \multirow{2}{*}{ Czynniki } & \multicolumn{2}{|c|}{ Kobiety } & \multicolumn{2}{c|}{ Mężczyźni } \\
\cline { 2 - 5 } & średnia & $\begin{array}{c}\text { odchylenie } \\
\text { standardowe }\end{array}$ & średnia & $\begin{array}{c}\text { odchylenie } \\
\text { standardowe }\end{array}$ \\
\hline Samorealizacja & 3,25 & 0,595 & 3,26 & 0,675 \\
\hline $\begin{array}{l}\text { Wyzwania i działania wymagające twórczości } \\
\text { i inicjatywy }\end{array}$ & 3,13 & 0,689 & 2,96 & 0,721 \\
\hline Samodzielnie stawiane cele & 3,17 & 0,685 & 3,02 & 0,642 \\
\hline Odczuwanie sensu działania & 3,56 & 0,532 & 3,51 & 0,655 \\
\hline $\begin{array}{l}\text { Równowaga między życiem osobistym a zawo- } \\
\text { dowym }\end{array}$ & 3,59 & 0,638 & 3,49 & 0,748 \\
\hline Zapewnienie bezpieczeństwa socjalnego & 3,49 & 0,619 & 3,36 & 0,735 \\
\hline
\end{tabular}

Źródło: opracowanie własne. 
Średnia ocena istotności równowagi między życiem osobistym a zawodowym jest najważniejsza i w przybliżeniu taka sama dla obu płci (odpowiednio kobiety: 3,59 oraz mężczyźni: 3,49). Najmniejsze znaczenie (także dla obu płci) mają wyzwania i działania wymagające twórczości i inicjatywy, a co więcej, odpowiedzi dotyczące tego czynnika są najbardziej zróżnicowanie wśród grupy kobiet $(0,689)$. W grupie mężczyzn odpowiedzi najbardziej odbiegające od średniej występowały w przypadku równowagi między życiem osobistym a zawodowym $(0,748)$.

Analiza odpowiedzi na pytanie zawarte w kwestionariuszu ankiety: „Jak przypuszczasz - które środki będą Ciebie skuteczniej motywowały do pracy?" została przedstawiona w tabeli 25 .

Tabela 25. Środki najskuteczniej motywujące do pracy ( $w \%)$

\begin{tabular}{|l|c|c|c|}
\hline $\begin{array}{c}\text { Środki motywacji } \\
\text { do pracy }\end{array}$ & $\begin{array}{c}\text { Cała } \\
\text { próba }\end{array}$ & Kobiety & $\begin{array}{c}\text { Męż- } \\
\text { czyźni }\end{array}$ \\
\hline Przymusu & 10,0 & 6,3 & 14,9 \\
\hline Zachęty & 90,0 & 93,7 & 85,1 \\
\hline
\end{tabular}

Źródło: opracowanie własne.

Prawie 94\% respondentek i ponad $85 \%$ respondentów przypuszcza, że to właśnie środki zachęty byłyby dla nich najskuteczniejszymi motywatorami do efektywnej pracy. Jedynie $10 \%$ całej badanej próby twierdzi, że jedynie przez środki przymusu mogliby zostać zmotywowani do działa- nia. Z kolei analiza odpowiedzi na pytanie: „Jak przypuszczasz - co będzie Ciebie efektywniej motywowało do pracy?" została zamieszczona w tabeli 26.

Za najefektywniejsze w motywowaniu do pracy środki zachęty respondenci uznali bodźce materialne $(3,54)$ oraz nagradzanie za wykonanie działań znajdujących się poza zakresem obowiązków $(3,49)$. Natomiast za najmniej efektywne uznane zostały bodźce niematerialne $(2,93)$. Może to świadczyć o tym, że obecnie efektywniejsze w motywowaniu, od pochwał czy udziału w kursach doszkalających organizowanych przez pracodawcę, są bodźce takie jak premie lub telefon czy mieszkanie służbowe. Mając na uwadze zróżnicowanie udzielanych odpowiedzi, to w najwyższym stopniu dotyczy to tzw. trzynastki $(\delta=0,845)$ oraz właśnie omawianych wyżej bodźców niematerialnych $(\delta=0,794)$. Rozkłady odpowiedzi dotyczących wszystkich czynników charakteryzują się ujemną, lewostronną asymetria, lecz najsilniejsza występuje przy nagradzaniu za wykonanie działań znajdujących się poza zakresem obowiązków $\left(\gamma_{3}=-1,205\right)$, także rozkład odpowiedzi dotyczących tego środka jest najbardziej leptokurtyczny - wysmukły, czyli cechuje się małym zróżnicowaniem odpowiedzi osób w próbie $\left(\gamma_{4}=1,044\right)$. $\mathrm{Z}$ kolei bodźce niematerialne oraz uczenie pracowników wykonywania wymaganych od nich działań (odpowiednio $\gamma_{4}$ wynosi $-0,823$ oraz $-0,702)$ mają rozkład odpowiedzi najwyraźniej spłaszczony w stosunku do rozkładu normalnego (platokurtyczne),

Tabela 26. Ocena przypuszczalnej skuteczności środków zachęty w efektywnym motywowaniu do pracy w całej próbie

\begin{tabular}{|c|c|c|c|c|c|c|}
\hline Środki zachęty & 惢 & 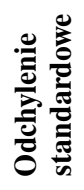 & 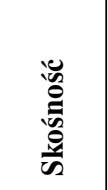 & 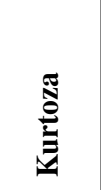 & 志 & 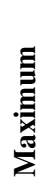 \\
\hline $\begin{array}{l}\text { Uczenie pracowników wykonywania wymaganych od } \\
\text { nich działań }\end{array}$ & 3,17 & 0,660 & $-0,191$ & $-0,702$ & 2 & 4 \\
\hline Tzw. trzynastka & 3,26 & 0,845 & $-0,840$ & $-0,218$ & 1 & 4 \\
\hline $\begin{array}{l}\text { Nagradzanie za wykonanie działań znajdujących się } \\
\text { poza zakresem obowiązków }\end{array}$ & 3,49 & 0,679 & $-1,205$ & 1,044 & 1 & 4 \\
\hline Bodźce materialne & 3,54 & 0,578 & $-0,803$ & $-0,331$ & 2 & 4 \\
\hline Bodźce niematerialne & 2,93 & 0,794 & $-0,125$ & $-0,823$ & 1 & 4 \\
\hline
\end{tabular}

Źródło: opracowanie własne. 
Tabela 27. Różnice między kobietami a mężczyznami w zakresie postrzegania motywacyjnej efektywności poszczególnych środków zachęty

\begin{tabular}{|l|c|c|c|c|}
\hline \multirow{2}{*}{ Środki zachęty } & \multicolumn{2}{c|}{ Kobiety } & \multicolumn{2}{c|}{ Mężczyźni } \\
\cline { 2 - 5 } & średnia & $\begin{array}{c}\text { odchylenie } \\
\text { standardowe }\end{array}$ & średnia & $\begin{array}{c}\text { odchylenie } \\
\text { standardowe }\end{array}$ \\
\hline $\begin{array}{l}\text { Uczenie pracowników wykonywania wymaga- } \\
\text { nych od nich działań }\end{array}$ & 3,18 & 0,658 & 3,15 & 0,670 \\
\hline Tzw. trzynastka & 3,28 & 0,744 & 3,23 & 0,986 \\
\hline $\begin{array}{l}\text { Nagradzanie za wykonanie działań znajdujących } \\
\text { się poza zakresem obowiązków }\end{array}$ & 3,55 & 0,597 & 3,41 & 0,785 \\
\hline Bodźce materialne & 3,53 & 0,569 & 3,54 & 0,600 \\
\hline Bodźce niematerialne & 2,91 & 0,708 & 2,95 & 0,916 \\
\hline
\end{tabular}

Źródło: opracowanie własne.

co świadczy o dość wyraźnym zróżnicowaniu odpowiedzi dotyczących tych środków zachęty.

Przeciętne oceny efektywności nagradzania za wykonanie działań znajdujących się poza zakresem obowiązków $(3,55)$ oraz bodźców materialnych $(3,53)$ są najwyższe zarówno w grupie kobiet, jak i mężczyzn, lecz w odwrotnej kolejności - najefektywniejsze są w grupie mężczyzn bodźce materialne $(3,54)$, a zaraz za nimi nagradzanie za wykonanie działań znajdujących się poza zakresem obowiązków $(3,41)$ (tab. 27). Płeć nie odgrywa roli, jeżeli chodzi o wyłonienie najmniej efektywnych środków zachęty. W obu grupach są to bodźce niematerialne (odpowiednio kobiety: 2,91 oraz mężczyźni: 2,95). Także w obu grupach respondentów największe odchylenia odpowiedzi od średniej występowały przy środku zachęty: tzw. trzynastka.

Ocenę przypuszczalnej skuteczności rodzajów motywacji w motywowaniu do pracy przedstawia tabela 28.

Prawie $86 \%$ respondentek i $83 \%$ respondentów przypuszcza, że motywacja płacowa byłaby dla nich skuteczniejszym rodzajem motywacji do efektywnej pracy od motywacji pozapłacowej. Raptem 14,3\% ankietowanych studentek oraz $17 \%$ studentów twierdzi, że mogliby zostać zmotywowani do działania jedynie przez motywację pozapłacową.

Analizę odpowiedzi udzielonych na pytanie dotyczące przypuszczeń na temat efektywności poszczególnych motywatorów pozapłacowych i ich wpływu na skuteczność pracy zawiera tabela 29.

Za najefektywniejsze motywatory pozapłacowe uznano, średnio w całej próbie, pracę gwarantującą zadowalającą ilość czasu na życie rodzinne $(3,29)$ oraz otrzymanie samochodu służbowego $(3,24)$. Także te motywatory charakteryzują się najistotniejszym zróżnicowaniem udzielanych odpowiedzi - odpowiednio $\delta=0,985$ oraz $\delta=0,970$. Przeciętnie za najmniej skuteczne uznano ex aequo skrócony tydzień pracy oraz mieszkanie służbowe $(2,76)$ ze zróżnicowaniem odpowiedzi na poziomie $\delta=0,831$. W przypadku pakietu opieki medycznej brakuje asymetrii, natomiast rozkłady pozostałych odpowiedzi charakteryzują się ujemną, lewostronną asymetrią. Najsilniejsza występuje przy odpowiedziach dotyczących pracy gwarantującej zadowalającą ilość czasu na życie rodzinne $\left(\gamma_{3}=-1,121\right)$. Motywator ten charakteryzuje się także najmniejszym zróżnicowaniem odpowiedzi $\left(\gamma_{4}=0,076\right)$ - jest leptokurtyczny (wysmukły). Z kolei rozkład odpowiedzi dotyczących pakietu

Tabela 28. Przypuszczalna skuteczność rodzajów motywacji w motywowaniu do pracy (w \%)

\begin{tabular}{|l|c|c|c|}
\hline \multicolumn{1}{|c|}{ Rodzaje motywacji } & Cała próba & Kobiety & Mężczyźni \\
\hline Motywacja płacowa & 84,5 & 85,7 & 83,0 \\
\hline Motywacja pozapłacowa & 15,5 & 14,3 & 17,0 \\
\hline
\end{tabular}

Źródło: opracowanie własne. 


\begin{tabular}{|c|c|c|c|c|c|c|}
\hline Motywatory pozapłacowe & 呾 & 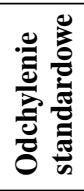 & 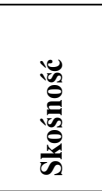 & 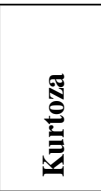 & 志 & $\begin{array}{l}\text { 国 } \\
\text { 离 } \\
\text { 离 }\end{array}$ \\
\hline Skrócony tydzień pracy & 2,76 & 0,903 & $-0,054$ & $-0,775$ & 1 & 4 \\
\hline $\begin{array}{l}\text { Praca gwarantująca zadowalającą ilość czasu na } \\
\text { życie rodzinne }\end{array}$ & 3,29 & 0,985 & $-1,121$ & 0,076 & 1 & 4 \\
\hline Pakiet opieki medycznej & 3,00 & 0,791 & 0,000 & $-1,326$ & 2 & 4 \\
\hline $\begin{array}{l}\text { Pakiet umożliwiający korzystanie z obiektów spor- } \\
\text { towych i rekreacyjnych }\end{array}$ & 3,12 & 0,857 & $-0,245$ & $-1,628$ & 2 & 4 \\
\hline Mieszkanie służbowe & 2,76 & 0,831 & $-0,243$ & $-0,146$ & 1 & 4 \\
\hline Samochód służbowy & 3,24 & 0,970 & $-0,997$ & $-0,055$ & 1 & 4 \\
\hline Publiczne lub indywidualne słowa uznania & 3,06 & 0,748 & $-0,099$ & $-1,047$ & 2 & 4 \\
\hline
\end{tabular}

Źródło: opracowanie własne.

umożliwiającego korzystanie z obiektów sportowych i rekreacyjnych jest najbardziej platokurtyczny (wyraźnie spłaszczony w stosunku do rozkładu normalnego), co świadczy o wyraźnym zróżnicowaniu odpowiedzi na temat tego motywatora.

Najwyżej ocenianym motywatorem pod względem skuteczności jest według kobiet praca gwarantująca zadowalającą ilość czasu na życie rodzinne $(3,56)$. Wyniki uwidaczniają fakt, że kobiety już od najmłodszych lat wychowywane są w duchu kulturowej roli społecznej i przypuszczają one, że efektywnie będą mogły pracować jedynie wtedy, gdy będą miały pewność, że znajdą czas także na swoje obowiązki i przyjemności związane $z$ prowadzeniem domu, a nie tylko na obowiązki zawodowe (tabela 30). Mężczyźni z kolei za najefektywniejszy motywator uznali otrzymanie samochodu służbowego $(3,25)$. Płeć nie odgrywa natomiast kluczowej roli, jeżeli chodzi o wyłonienie najmniej efektywnego motywatora pozapłacowego. W obu grupach jest to mieszkanie służbowe. Największe zróżnicowanie odpowiedzi w grupie kobiet wystąpiło w ocenie skuteczności motywatora, jakim jest samochód służbowy

Tabela 30. Różnice pomiędzy kobietami a mężczyznami w zakresie postrzegania skuteczności poszczególnych motywatorów pozapłacowych

\begin{tabular}{|l|c|c|c|c|}
\hline \multirow{2}{*}{ Motywatory pozapłacowe } & \multicolumn{2}{c|}{ Kobiety } & \multicolumn{2}{c|}{ Mężczyźni } \\
\cline { 2 - 5 } & średnia & $\begin{array}{c}\text { odchylenie } \\
\text { standardowe }\end{array}$ & średnia & $\begin{array}{c}\text { odchylenie } \\
\text { standardowe }\end{array}$ \\
\hline Skrócony tydzién pracy & 3,00 & 0,866 & 2,50 & 0,926 \\
\hline $\begin{array}{l}\text { Praca gwarantująca zadowalającą ilość czasu na } \\
\text { życie rodzinne }\end{array}$ & 3,56 & 0,726 & 3,00 & 1,195 \\
\hline Pakiet opieki medycznej & 3,11 & 0,782 & 2,88 & 0,835 \\
\hline $\begin{array}{l}\text { Pakiet umożliwiający korzystanie z obiektów } \\
\text { sportowych i rekreacyjnych }\end{array}$ & 3,33 & 0,866 & 2,88 & 0,835 \\
\hline Mieszkanie służbowe & 2,78 & 0,972 & 2,75 & 0,707 \\
\hline Samochód służbowy & 3,22 & 1,093 & 3,25 & 0,886 \\
\hline Publiczne lub indywidualne słowa uznania & 3,33 & 0,707 & 2,75 & 0,707 \\
\hline
\end{tabular}

Źródło: opracowanie własne. 
(1,093), a w grupie mężczyzn w przypadku pracy gwarantującej zadowalającą ilość czasu na życie rodzinne $(1,195)$.

\section{Badanie zależności między motywacją a pozostałymi zmiennymi}

W tej części artykułu zostaną przedstawione najważniejsze zależności występujące między poziomem motywacji a:

- posiadanymi „miękkimi” kompetencjami,

- planami na przyszłość,

- doświadczeniem na praktykach studenckich oraz w pracy,

- oceną istotności czynników występujących w pracy,

- oceną skuteczności sposobów motywowania, w tym także środków zachęty i motywatorów pozapłacowych, zarówno w całej próbie, jak i w podziale na grupy wyodrębnione ze względu na płeć.

Ze względu na fakt, iż nie wszystkie analizowane zmienne charakteryzowały się rozkładem normalnym, występowanie związków między wymienionymi wyżej czynnikami poddano badaniu z wykorzystaniem statystyki nieparametrycznej, czyli współczynnika korelacji tau-b Kendalla. $\mathrm{W}$ pierwszej kolejności opisane zostaną korelacje, a następnie inne zależności pomiędzy zmiennymi.

\section{„Miękkie” kompetencje a poziom motywacji}

Przeprowadzona analiza wskazała na występowanie istotnej statystycznie korelacji między poziomem motywacji a wiarą $\mathrm{w}$ siebie $\mathrm{w}$ grupie mężczyzn (tau $=0,290$, $\mathrm{p}<0,05)$ oraz na występowanie zależności na poziomie tendencji statystycznej dla ogółu badanych (tau $=0,170$, $\mathrm{p}=0,057$, więc prawie 0,05$). \mathrm{Z}$ analizy wynika, że wyższy poziom motywacji wiąże się z większą wiarą we własne możliwości (tabela 31). Istotne statystycznie korelacje poziomu motywacji $\mathrm{z}$ przedsiębiorczością, zaradczością i sprytem wystąpiły także w grupie wszystkich respondentów $(\mathrm{tau}=0,195, \mathrm{p}<0,05)$ oraz $\mathrm{w}$ grupie mężczyzn (tau $=0,288, p<0,05)$, co świadczy o tym, że poziom motywacji rośnie wraz z rozwojem swych cech przedsiębiorczych. $\mathrm{Z}$ kolei istotne statystycznie korelacje poziomu motywacji z chęcią ciągłego uczenia się ukazały się dla ogółu respondentów (tau $=0,232, \mathrm{p}<0,01$ ) oraz $\mathrm{w}$ grupie kobiet (tau $=0,300, p<0,05)$, tak więc można przypuszczać, że wyższa motywacja idzie w parze $\mathrm{z}$ chęcią ciągłego dokształcania. Istotne statystycznie korelacje poziomu

Tabela 31. Poziom motywacji a „miękkie” kompetencje - współczynnik korelacji tau-b Kendalla

\begin{tabular}{|l|c|c|c|}
\hline \multicolumn{4}{|c|}{ Poziom motywacji } \\
\hline \multirow{2}{*}{ „Miękkie” kompetencje } & \multicolumn{2}{|c|}{ Współczynnik korelacji tau-b Kendalla } \\
\cline { 2 - 4 } & cała próba & kobiety & mężczyźni \\
\hline Automotywacja & 0,013 & $-0,039$ & 0,068 \\
\hline Wiara w siebie & $0,170(\mathrm{t})$ & 0,061 & $0,290^{*}$ \\
\hline Inteligencja & 0,157 & 0,110 & 0,204 \\
\hline Przedsiębiorczość, zaradność, spryt & $0,195^{*}$ & 0,157 & $0,288^{*}$ \\
\hline Chęć ciągłego uczenia się & $0,232^{* *}$ & $0,300^{*}$ & 0,132 \\
\hline Zaangażowanie w wykonywane czynności & $0,289^{* *}$ & $0,257^{*}$ & $0,323^{*}$ \\
\hline Gotowość do podejmowania ryzyka & 0,165 & 0,142 & 0,200 \\
\hline Odporność na stres & 0,142 & $-0,005$ & $0,309^{*}$ \\
\hline Umiejętność chwytania nadarzających się okazji & 0,088 & 0,097 & 0,086 \\
\hline Skłonność do wyrzeczeń i poświęceń & 0,061 & 0,180 & $-0,104$ \\
\hline Umiejętność skutecznej komunikacji & $0,195^{*}$ & 0,154 & 0,217 \\
\hline
\end{tabular}

* Korelacja jest istotna na poziomie 0,05 (dwustronnie).

** Korelacja jest istotna na poziomie 0,01 (dwustronnie).

*** Korelacja jest istotna na poziomie 0,001 (dwustronnie).

Źródło: opracowanie własne. 
motywacji z zaangażowaniem w wykonywane czynności charakteryzują zarówno ogół badanych (tau $=0,289, \mathrm{p}<0,01)$, grupe kobiet (tau $=0,257, \mathrm{p}<0,05)$, jak $\mathrm{i}$ grupę mężczyzn (tau $=0,323, \mathrm{p}<0,05)$, czyli wyższa motywacja dla wszystkich ankietowanych grup wiąże się $\mathrm{z}$ wyższym zaangażowaniem, co potwierdza drugą, postawioną w pracy hipotezę główną, że zaangażowanie w wykonywane czynności pozostaje $\mathrm{w}$ ścisłym związku z poziomem własnej motywacji. $\mathrm{Z}$ kolei istotna statystycznie korelacja poziomu motywacji $\mathrm{z}$ odpornością na stres wystąpiła jedynie $\mathrm{w}$ grupie mężczyzn ( $\mathrm{tau}=0,309$, $\mathrm{p}<0,05)$, natomiast $\mathrm{z}$ umiejętnością skutecznej komunikacji wystąpiła dla ogółu (tau $=0,195, p<0,05)$. Oznacza to, iz osoby potrafiące się skutecznie komunikować charakteryzują się wyższym poziomem motywacji. Wszystkie istotne statystycznie korelacje mają charakter dodatni, lecz są słabe lub charakteryzują się przeciętną siłą związku. Więcej istotnych statystycznie związków w przypadku poziomu motywacji i „miękkich” kompetencji nie zaobserwowano.

\section{Sposoby motywowania a poziom motywacji}

Analizy przeprowadzone dla poziomu motywacji i sposobów motywowania wykazały istnienie jednej istotnej statystycznie korelacji - jest to dodatnia, charakteryzująca się przeciętną siłą, istotna statystycznie korelacja poziomu motywacji z dodatkowymi gratyfikacjami za ponadprzeciętne efekty, która wystąpiła jedynie w grupie mężczyzn (tau $=0,369$, p < 0,05). Więcej istotnych statystycznie związków dla poziomu motywacji i sposobów motywowania nie zaobserwowano.

\section{Czynniki pracy a poziom motywacji}

Analizy przeprowadzone dla poziomu motywacji i czynników pracy, takich jak: samorealizacja, wyzwania i działania wymagające twórczości i inicjatywy, samodzielnie stawiane cele, odczuwanie sensu działania, równowaga między życiem osobistym a zawodowym oraz zapewnienie bezpieczeństwa socjalnego, wykazały istnienie trzech dodatnich, o przeciętnej sile związku, istotnych statystycznie korelacji. Dwie pierwsze $\mathrm{z}$ nich występują między poziomem motywacji a wyzwaniami i działaniami wymagającymi twórczości i inicja- tywy: dla ogółu badanych (tau $=0,250$, $\mathrm{p}<0,01)$ oraz dla kobiet (tau $=0,230$, $\mathrm{p}<0,05)$. Istotna statystycznie korelacja ujawniła się także między poziomem motywacji a samodzielne stawianymi celami, lecz tylko dla całej próby (tau $=0,172$, $\mathrm{p}<0,05)$, tak więc samodzielne stawiane cele idą $\mathrm{w}$ parze $\mathrm{z}$ poziomem motywacji. Więcej istotnych statystycznie związków w przypadku poziomu motywacji i czynników pracy nie zaobserwowano.

\section{Środki zachęty a poziom motywacji}

Analizy przeprowadzone dla poziomu motywacji i środków zachęty wykazały istnienie dodatnich, charakteryzujących się przeciętną siłą, istotnych statystycznie korelacji między poziomem motywacji a dwoma $\mathrm{z}$ wymienionych $\mathrm{w}$ ankiecie środków zachęty, a mianowicie: uczeniem pracowników wykonywania wymagania od nich działań dla ogółu badanych (tau $=0,219$, $\mathrm{p}<0,05)$ i dla kobiet (tau $=0,463$, $\mathrm{p}<0,01$ ) oraz nagradzaniem za wykonanie działań znajdujących się poza zakresem obowiązków, także dla ogółu (tau $=0,231$, $\mathrm{p}<0,05)$ i dla kobiet ( tau $=0,249$, $\mathrm{p}<0,05)$. Więcej istotnych statystycznie związków w przypadku poziomu motywacji i środków zachęty nie zaobserwowano.

\section{Motywatory pozapłacowe a poziom motywacji}

Analizy przeprowadzone dla poziomu motywacji i motywatorów pozapłacowych wykazały istnienie dodatnich, istotnych statystycznie korelacji między poziomem motywacji i otrzymywaniem przez pracownika pakietu opieki medycznej: o słabej sile związku dla ogółu (tau $=0,236$, $\mathrm{p}<0,05)$ oraz bardzo wysokiej sile związku $\mathrm{w}$ grupie kobiet $(\mathrm{tau}=0,832, \mathrm{p}<0,05)$, a także wysokiej korelacji między poziomem motywacji a publicznymi lub indywidualnymi słowami uznania, lecz tylko dla całej próby $($ tau $=0,520, \mathrm{p}<0,05)$. Więcej istotnych statystycznie związków w przypadku poziomu motywacji i motywatorami pozapłacowymi nie zaobserwowano.

W dalszej części artykułu zostaną poddane analizie zmienne o charakterze nominalnym, dla których nie liczy się korelacji, a jedynie zależności występujące pomiędzy nimi. 


\section{Poziom motywacji a plany zawodowe}

Ze względu na fakt, że w analizie SPSS testem $\chi^{2}$ występowały za małe liczebności oczekiwane i niespełnione było założenie leżące u odstaw tego testu, głoszące, że liczebności oczekiwane wynosić muszą w każdej komórce tabeli przynajmniej 5, wyniki analizy zostały zagregowane i z czterech możliwości wyboru odpowiedzi utworzono po dwie: przy pytaniu o plany zawodowe „nie" (w miejsce zdecydowanie nie" oraz „raczej nie”) oraz „tak” (w miejsce „raczej tak” i „zdecydowanie tak”), natomiast przy pytaniu o poziom motywacji „niski” (w miejsce ,zdecydowanie niski” i „raczej niski”) oraz „wysoki” (w miejsce „raczej wysoki” oraz ,zdecydowanie wysoki”). Wyniki analizy przedstawione są w tabeli 32 .

Tabela 32. Poziom motywacji a plany zawodowe dla całej próby ( $w$ \%)

\begin{tabular}{|l|c|c|}
\hline \multirow{2}{*}{$\begin{array}{c}\text { Posiadasz } \\
\text { plany zawodowe? }\end{array}$} & \multicolumn{2}{|c|}{ Poziom motywacji } \\
\cline { 2 - 3 } & niski & wysoki \\
\hline Nie & 63,2 & 33,0 \\
\hline Tak & 36,8 & 67,0 \\
\hline
\end{tabular}

$\chi_{(1)}^{2}=6,07, \mathrm{c}=0,229, \mathrm{p}<0,05$

Źródło: opracowanie własne.

Analiza rozkładu wskazuje, że 63,2\% badanej próby nie ma planów zawodowych i jednocześnie określa poziom swej motywacji jako niski, natomiast respondenci oceniający swoją motywację jako wysoką częściej mają sprecyzowane plany zawodowe $(67 \%)$. $Z$ tego też względu istnieje istotny statystycznie związek między poziomem własnej motywacji a posiadaniem sprecyzowanych planów zawodowych $\left(\chi^{2}(1)\right.$ $=6,07, \mathrm{p}<0,05)$, ale jest słaby (wspó1czynnik kontyngencji: $\mathrm{c}=0,229, \mathrm{p}<0,05)$, co potwierdza pierwszą postawioną $\mathrm{w}$ pracy hipotezę główną, iż posiadanie sprecyzowanych planów zawodowych na przyszłość pozostaje w związku z subiektywnie ocenianym poziomem motywacji.

\section{Doświadczenie w pracy a poziom motywacji}

Ze względu na fakt, iż w analizie SPSS testem $\chi^{2}$ występowały za małe liczebności oczekiwane i niespełnione było założenie leżące u odstaw tego testu, głoszące, iż liczebności oczekiwane wynosić muszą w każdej komórce tabeli przynajmniej 5, wyniki analizy zostały zagregowane i z czterech możliwości wyboru odpowiedzi utworzono po dwie przy pytaniu o poziom motywacji: „niski” (w miejsce ,zdecydowanie niski” i „raczej niski”) oraz „wysoki” (w miejsce „raczej wysoki” oraz „,zdecydowanie wysoki”). Wyniki analizy zostały zawarte w tabeli 33.

Tabela 33. Poziom motywacji a doświadczenie $w$ pracy dla całej próby ( $w$ \%)

\begin{tabular}{|l|c|c|}
\hline \multirow{2}{*}{ Pracowałeś już? } & \multicolumn{2}{c|}{ Poziom motywacji } \\
\cline { 2 - 3 } & niski & wysoki \\
\hline Nie & 52,6 & 26,4 \\
\hline Tak & 47,4 & 73,6 \\
\hline
\end{tabular}

$\chi^{2}{ }_{(1)}=5,075, \mathrm{c}=0,21, \mathrm{p}<0,05$

Źródło: opracowanie własne.

Istnieje istotny związek między poziomem własnej motywacji a posiadaniem doświadczeń zawodowych $\left(\chi^{2}{ }_{(1)}=5,075\right.$, $\mathrm{p}<0,05$ ), lecz jest on słaby (współczynnik kontyngencji: $\mathrm{c}=0,21, \mathrm{p}<0,05)$. Analiza rozkładu odpowiedzi wskazuje, że osoby oceniające swoja motywację jako wysoką częściej mają doświadczenia zawodowe $(73,6 \%)$. Natomiast osoby o niskim poziomie motywacji częściej nie mają dotychczas żadnego doświadczenia zawodowego $(52,6 \%)$.

\section{Obowiązkowe praktyki studenckie a poziom motywacji}

Ze względu na fakt, iż w analizie SPSS testem $\chi^{2}$ występowały za małe liczebności oczekiwane i niespełnione było założenie leżące u podstaw tego testu, głoszące iż liczebności oczekiwane muszą wynosić w każdej komórce tabeli przynajmniej 5, wyniki analizy zostały zagregowane i z czterech możliwości wyboru odpowiedzi utworzono po dwie, przy pytaniu o poziom motywacji: „niski” (w miejsce „zdecydowanie niski” i „raczej niski”) oraz „wysoki” (w miejsce „raczej wysoki” oraz ,zdecydowanie wysoki”). Wyniki analizy prezentuje tabela 34 .

Występuje istotny statystycznie związek między poziomem własnej motywacji a posiadaniem doświadczeń zawodowych innych niż obowiązkowe praktyki studenckie $\left(\chi_{(1)}^{2}=5,719, \mathrm{p}<0,05\right)$, ale także jest on słaby (współczynnik kontyngencji: 
$\mathrm{c}=0,224, \mathrm{p}<0,05)$. Analiza rozkładu odpowiedzi wskazuje, że osoby oceniające swoją motywację jako wysoką częściej mają doświadczenia zawodowe inne niż obowiązkowe praktyki studenckie.

Tabela 34. Poziom motywacji a doświadczenie inne niż obowiązkowe praktyki studenckie dla całej próby ( $w$ \%)

\begin{tabular}{|l|c|c|}
\hline \multirow{2}{*}{$\begin{array}{c}\text { Posiadasz doświadczenie } \\
\text { inne niż obowiązkowe prak- } \\
\text { tyki? }\end{array}$} & \multicolumn{2}{|c|}{$\begin{array}{c}\text { Poziom moty- } \\
\text { wacji }\end{array}$} \\
\cline { 2 - 3 } & niski & wysoki \\
\hline Nie & 57,9 & 29,2 \\
\hline Tak & 42,1 & 70,8 \\
\hline
\end{tabular}

$\chi^{2}{ }_{(1)}=5,719, \mathrm{c}=0,224, \mathrm{p}<0,05$

Źródło: opracowanie własne.

Z przeprowadzonych badań wynika, że posiadanie sprecyzowanych planów zawodowych na przyszłość pozostaje w ścisłej korelacji z subiektywnie ocenianym poziomem motywacji. Otrzymane wyniki potwierdzają przyjęte w pracy założenie, iż zaangażowanie w wykonywane czynności pozostaje $\mathrm{w}$ ścisłym związku z poziomem własnej motywacji studenta. Co więcej, wyniki zaprezentowane w niniejszym rozdziale wskazują także na różnice percepcji w grupie kobiet i mężczyzn. $\mathrm{Z}$ prezentowanych analiz wynika, że otrzymywanie pochwał nie jest tak samo skutecznym motywatorem dla kobiet, jak dla mężczyzn. Istnieją także różnice $\mathrm{w}$ ocenie poziomu własnej motywacji do rozpoczęcia pracy zawodowej oraz $\mathrm{w}$ postrzeganej istotności znajomości języków obcych dla rozwoju kariery zawodowej w grupie kobiet i mężczyzn.

\section{Podsumowanie}

Intensywne i radykalne zmiany zachodzące na rynku pracy i w sposobie funkcjonowania przedsiębiorstw skutkują zarówno zmianami w wykorzystywanych przez przełożonych metodach motywowania i ich skuteczności, jak i zmianami systemu wartości i oczekiwań pracowników wobec firm, w których pracują. W dzisiejszych czasach organizacje poszukują ludzi energicznych, mobilnych, zaradnych i operatywnych, którzy sprostają stawianym im wymaganiom bycia multifunkcyjnym, innowacyjnym, elastycznym, dynamicznym w działaniu czy skłonnym do ryzyka, co przełożyć ma się w ostateczności na sukces firmy i jej powodzenie na zmiennym, burzliwym i konkurencyjnym rynku.

Uwalnianie powyższych aktywności i cech staje się możliwe jedynie przy wykorzystywaniu odpowiedniego systemu motywacyjnego. Stanowić powinien on sekwencję bodźców, środków, narzędzi oraz warunków pracy, które mają na celu pobudzanie i mobilizowanie pracowników do aktywnego uczestnictwa i pełnego zaangażowania w pełnione obowiązki oraz dostarczanie im satysfakcji z pracy.

Przeprowadzona w artykule analiza niewątpliwie potwierdziła prawdziwość i trafność sformułowanych hipotez badawczych: zarówno głównych, jak i cząstkowych. Na podstawie bogatego materiału faktograficznego zaobserwowano, że motywacja postrzegana jest przez studentów studiów niestacjonarnych Wydziału Zarządzania Uniwersytetu Warszawskiego jako czynnik ułatwiający rozpoczęcie kariery i powodzenie na rynku pracy.

Z przeprowadzonych badań wynika także, że aż $92,5 \%$ badanej próby było zdania, że ich kariera zawodowa zależy od nich samych. Natomiast analiza wpływu determinantów zewnętrznych wskazuje, że za najistotniejsze - zarówno w grupie ankietowanych kobiet, jak i w grupie mężczyzn - uznane zostały znajomości. Należy także zaznaczyć, że na podstawie materiału faktograficznego stwierdzono istnienie związku między posiadaniem sprecyzowanych planów zawodowych na przyszłość a subiektywnie ocenianym poziomem własnej motywacji. Analiza rozkładu odpowiedzi wskazała, że studenci oceniający swoją motywację jako wysoką częściej mają plany zawodowe. Otrzymane wyniki potwierdzają także trafność założenia, iż zaangażowanie w wykonywane czynności pozostaje w ścisłym związku z poziomem motywacji ankietowanego studenta. Ponadto zilustrowanie zaprezentowanych analiz materiałem faktograficznym, stanowiącym uwiarygodnienie sformułowanych konkluzji wyraźnie wskazuje na występowanie inności postrzegania w grupie kobiet i mężczyzn. Z prezentowanych analiz wynika, że istnieją różnice w ocenie poziomu własnej motywacji do rozpoczęcia pracy zawodowej, lecz także w percepcji istotności znajomości języków obcych dla rozwoju kariery w grupie kobiet 
i w grupie mężczyzn. W badaniu zidentyfikowano także fakt, iż otrzymywanie pochwał jest motywatorem wykorzystywanym efektywniej w stosunku do kobiet aniżeli do mężczyzn.

\section{Bibliografia}

Adamiec, M., Kożusznik, B. (2000). Zarządzanie zasobami ludzkimi. Aktor - Kreator - Inspirator. Kraków: Wydawnictwo Akade.

Altmann, H.Ch. (1997). Mut zu neuen Kunden. Motivation Und Strategien. Lansberg: Verlag Moderne Industrie.

Amstrong, M. (1996). Zarzadzanie zasobami ludzkimi. Strategia i dziatanie. Kraków: Wydawnictwo Profesjonalnej Szkoły Biznesu.

Borkowska, S. (1985). System motywowania w przedsiębiorstwie. Warszawa: PWN.

Borkowska, S. (2006). Motywacja i motywowanie. w: Król, H., Ludwiczyński, A. (red.), Zarzadzanie zasobami ludzkimi. Tworzenie kapitału ludzkiego organizacji. Warszawa: Wydawnictwo Naukowe PWN.
Brady, Ch. i Macleod, D. (2011). O krok dalej. Jak motywować pracowników. Warszawa: Wolters Kluwer Polska.

Erpenbeck, J. (1984). Motivation. Ihre Psychologie und Philosophie. Berlin: Akademie-Verlag.

Jasiński, Z. (2007). Proces motywacyjny i jego przebieg. w: Jasiński, Z. (red.), Motywowanie w przedsiębiorstwie. Uwalnianie ludzkiej produktywności. Materialne, organizacyjne $i$ psychologiczne motywatory. Warszawa: Agencja Wydawnicza „Placet”.

Juchnowicz, M. (2012). Zaangażowanie pracowników. Sposoby oceny $i$ motywowania. Warszawa: PWE.

Kopertyńska, M. (2009). Motywowanie pracowników. Warszawa: Wydawnictwo Placet.

Kozłowski, W. (2009). Zarządzanie motywacja pracowników. Warszawa: Wydawnictwo Cedewu.

Reykowski, J. (1992). Motywacja. W: Tomaszewski, T. (red.), Psychologia ogólna. Warszawa: PWN.

Sekuła, Z. (2008). Motywowanie do pracy. Teorie $i$ instrumenty. Warszawa: PWE.

Zalega, T. (2012). Konsumpcja. Determinanty, teorie $i$ modele. Warszawa: PWE. 